\title{
EL CALVARIO DE LA REDENCIÓN DE VICENT MACIP EN EL CONTEXTO VALENCIANO DE LAS VITAE CHRISTI MEDIEVALES*
}

\author{
POR \\ LLUÍS RAMON I FERRER ${ }^{1}$ \\ Universidad Católica de Valencia San Vicente Mártir
}

\section{RESUMEN}

Este trabajo consiste en una aproximación iconográfica e iconológica al cuadro titulado el Calvario de la Redención de Vicent Macip cuyo discurso visual explica la muerte redentora de Cristo, la superioridad de este sacrificio frente al culto levítico y el valor universal de la Redención y, al mismo tiempo, materializa los elementos necesarios para la contemplación de uno de los artículos del Credo: descendit ad inferos. En el análisis iconográfico, se han estudiado tres aspectos: el paisaje, las relaciones establecidas entre los personajes y la gestualidad. En la comparación del tema del cuadro con posibles fuentes literarias, se ha podido observar el paralelismo existente entre el tema pintado en el cuadro y su narración en la Vida de Jesucrist de Francesc Eiximenis.

PALABRAS CLAVE: Francesc Eiximenis; Vita Christi; gestualidad; Vicent Macip; descendit ad inferos.

\section{VICENT MACIP'S REDEMPTION CALVARY IN THE VALENCIAN CONTEXT OF MEDIEVAL VITAE CHRISTI}

\begin{abstract}
This paper consists in an iconographic and iconological approach to Vicent Macip's Redemption Calvary, whose visual discourse explains the redeeming death of Christ, the superiority of His sacrifice over levitical worship and the universal Redemption value. At the same time, it provides the necessary elements for the contemplation of one of the articles of the Catholic Creed: descendit ad inferos (he descended into Hell). At the iconographic analysis, three aspects have been studied: landscape, relationships between characters and gestures. After comparing the painting subject with possible literary sources, we have been able to observe the parallelism between the painted theme in the paintinig and Francesc Eiximenis' Vida de Jesucrist narration.
\end{abstract}

KEY WORDS: Francesc Eiximenis; Vita Christi; gesture; Vicent Macip; descendit ad inferos.

Cómo CITAR ESTE ARTículo / CITATION: Ramon i Ferrer, Lluís. 2021. «El Calvario de la Redención de Vicent Macip en el contexto valenciano de las Vitae Christi medievales». Hispania Sacra LXXIII, 148: 373-387. https://doi.org/10.3989/hs.2021.029

Recibido/Received 16-03-2020

Aceptado/Accepted 30-05-2020

El 4 de noviembre de 2004, Pere M.a Orts Bosch donó a la Generalitat Valenciana su colección de obras de arte mediante la cual el museo San Pío V aumentó no solamente el número de piezas artísticas sino también la representatividad de movimientos estéticos.

Este artículo se inscribe en el proyecto MICINN, La cultura literaria medieval y moderna en la tradición manuscrita e impresa (VI), REF. FFI2017-83960-P (AEI/FEDER, UE).

1 Iluis.ramon@ucv.es / ORCID iD: https://orcid.org/0000-00028075-5977

\section{DESCRIPCIÓN DEL CUADRO}

Con el número de inventario 161/2004 del mencionado museo, se encuentra la tabla pintada al óleo procedente de la Donación Orts-Bosch. Se trata del Calvario de la Redención $\left(189\right.$ x 112,5), obra de ViMacip. ${ }^{2}$ Esta pieza pintada alre-

2 Vicent Macip (c.1475-1550) Su vida y obra han generado grandes controversias entre los estudiosos. Fue el primero de una estirpe de pintores establecidos en Valencia por tres generaciones. Su obra está influida por Paolo da San Leocadio y Rodrigo de Osona y, posteriormente, por Sebastiano del Piombo cuya obra marcará un viraje 
dedor de 1525 es una obra de máximo interés visual ya que anuncia la etapa de esplendor del artista (Fig. 1).

FIGURA 1

Cuadro completo

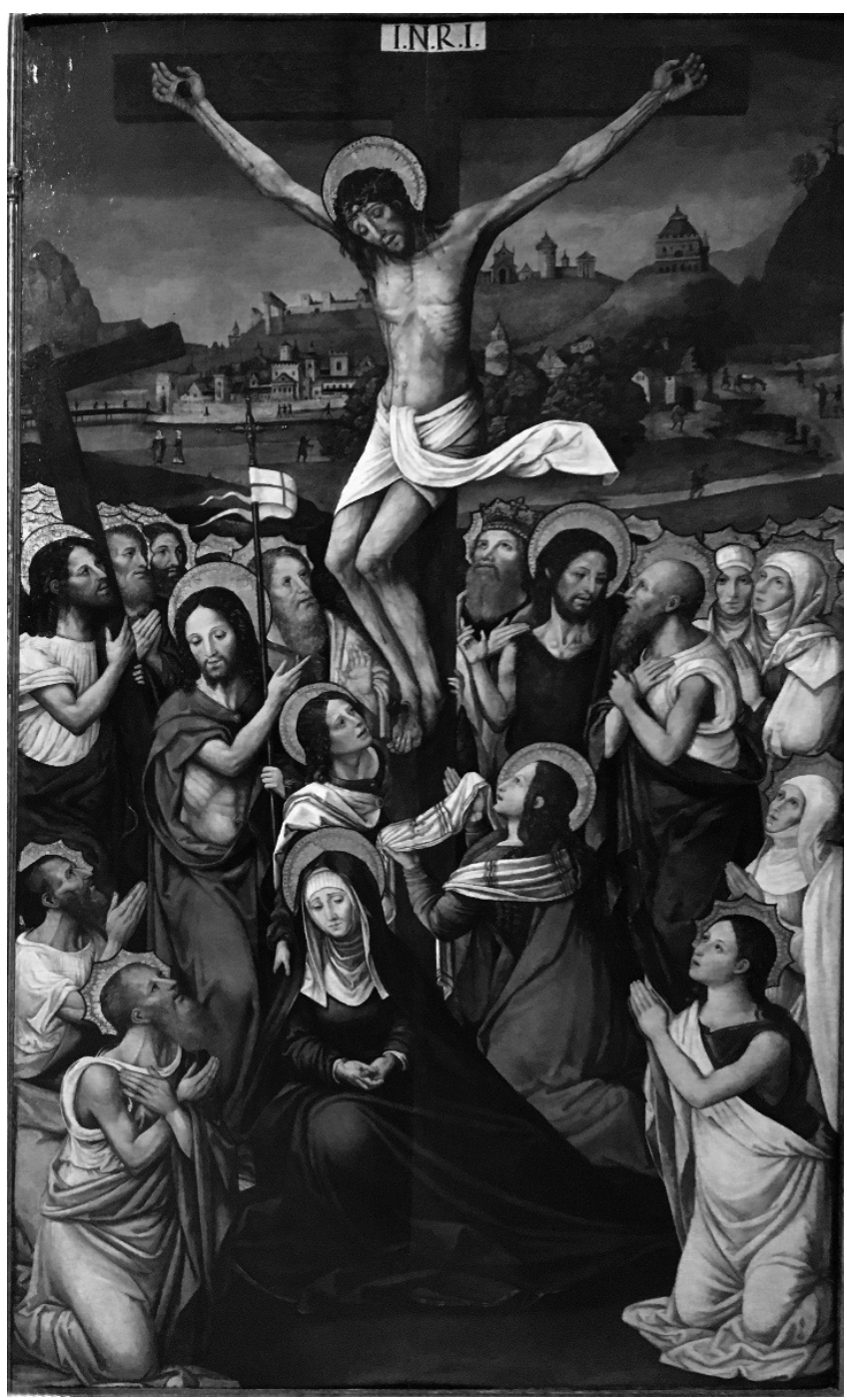

A finales del siglo XV y principios del XVI, los continuos contactos entre Flandes, Italia y Valencia generaron un caldo de cultivo de donde surgieron las primeras manifestaciones artísticas del Renacimiento en la ciudad del Turia. La innovación estética vino de la mano, fundamentalmente, de tres núcleos familiares: los Borja, los Vich y el formado por Mencía de Mendoza casada, sucesivamente, con Enrique de Nassau y con Fernando de Aragón, duque de Calabria. Paolo da San Leocadio y Francesco Pagano fueron promocionados en Valencia por los Borja; Jerónimo Vich introdujo en esta misma ciudad, entre otras muestras, algunas piezas artísticas de Sebastiano del Piombo; y Mencía de Mendoza

en la pintura de Macip hacia su etapa de madurez creativa por la que será conocido como el introductor del primer Renacimiento a España. Sobre Vicent Macip cfr. Martínez (1909-1910); Sanchis (1909); Tormo (1932); Garín (1955); Cerveró (1966); Albi (1979); Benito (1981, 1988, 1993); Arqués (1982); Vallés y Benito (1991); Samper (1994, 2001); Benito y Galdón (1997a, 1977b); Company y Tolosa (1997, 1999a, 1999b) y Tolosa, Company y Hernández (2006). fue la protectora de Jan van Scorel, Jan Cornelysz Vermeyen, Bernard van Orley, Martin van Heemskerk o Jan Gossaert. A partir de la inspiración tomada en estos artistas, los Macip pudieron crear el estilo definido y propio que les caracteriza (cfr. Ferrer y Ferrer 2015).

Macip elige la redención del linaje humano como tema de este cuadro que muestra a Jesús muerto en la cruz; a la derecha del crucificado se ve a san Juan Apóstol que, con una mano, toma a la Virgen mientras que con la otra se abraza al stipes; al lado izquierdo del crucificado, está representada María Magdalena con un lienzo en las manos con el que trata de empapar la sangre del Redentor. La Virgen, de espaldas a la imagen central, está sentada al pie de la cruz con las manos juntas y actitud de meditación dolorida. El cuerpo muerto de Jesucristo, sobre un paisaje que representa Jerusalén, ocupa el tercio superior del cuadro reservando los dos tercios inferiores a un grupo de dieciséis personajes mientras que, al fondo, se ve una gran cantidad de nimbos polilobulados que indican la multitud de los justos del Limbo.

Es necesario tener presente que el cuadro conforma un diagrama o discurso visual de carácter conceptual, que da lugar también a una tipología iconográfica muy peculiar que se podría titular: Calvario de la Redención, título también que porta esta obra en el catálogo del museo. Con el fin de aproximar una interpretación iconográfica, este trabajo se centra en tres aspectos que son el paisaje, referido a Jerusalén, las relaciones entre los personajes que aparecen y la gestualidad.

\subsection{Jerusalén}

Obviamente la muerte, pasión y resurrección de Cristo tuvo lugar en Jerusalén. Encuadrar la tipología iconográfica de esta obra en la ciudad santa, imponía pintar o bien una composición idealizada o bien una aproximación descriptiva inspirada en dibujos o escritos de viajeros que hubiesen podido estar en Tierra Santa.

El paisaje pintado por Vicent Macip es mayoritariamente verde y surcado por caminos donde unas siluetas hacen intuir personas que se dedican a diferentes labores. Aparecen cuatro montañas de las cuales, dos, las que ocupan los lados extremos del cuadro, no muestran ninguna construcción mientras que las dos centrales están edificadas, una de ellas presenta, en la cima, una fortaleza y en la base una ciudad amurallada a la orilla de un río. También se descubren ruinas clásicas. En la cumbre del otro montículo central se puede observar una construcción única, como una especie de templo y en su base, entre la masa forestal, se entrevén casas sueltas (Fig. 2).

El paisaje pintado coincide, a grandes rasgos, con el descrito por un peregrino: Bernardo de Breidenbach, deán de la catedral de Maguncia, quien, al regreso de un viaje a Tierra Santa, escribió un libro cuya traducción fue impresa en Zaragoza con el título Viaje de la Tierra Santa. ${ }^{3}$ Sobre la ciudad de Jerusalén dice:

Bernardo de Breidenbach, deán de la catedral de Maguncia, a la vuelta de una pregrinación a Tierra Santa escribió un libro que fue traducido del latín al castellano por Martin Martínez de Ampiés e impreso por Paulo Hurus en 1490 con el título Viaje de la tierra santa. El libro se había publicado en latín diez años antes en Alemania. Indudablemente Paulo Horus, impresor establecido en Zaragoza, intuyó el auténtico bestseller en que se iba a convertir esta obra que estuvo 
/98c. Cómo la ciudad de Jerusalén, según atestigua el rey, propheta y santo David sea fundamiento en los sanctos montes, no es maravilla que se hable dellos en lo general y particular, porque la Santa Scriptura faze mención muchas veces en sus lugares y casos diversos. [...] / 98d. Monte Syón era en Jerusalén en cuya cumbre stava fundada una fortaleza, que llamavan torre de David. Fue puesta ende por defender y hermosear la santa ciudad. En el un lado de Syón, estava fundado el templo quasi en medio de las dichas torres y Jerusalén, porque las altas fuerças toviessen más defendida la población que estaba puesta debajo dellas. / 99a [...] El monte Moria es en Jerusalen, donde fue fundado el templo de Salomón [...] este dicho monte, David le mercó de Ornán, jebuseo, por seiscientos siclos de oro puro, para que hiziesse templo a Dios, quando fue punido por el pecado de tentar el su pueblo [...] En este monte, dio sacrifio Abraam del cordero, quando el Señor mandó que su hijo sacrificasse y fue obediente [...] Este monte dizen, los judíos, que fue aquél donde fundaron después el templo / 99b [...] Este monte fue un solo collado, puesto en una ladera del monte Syón en donde se halla ser hedificada la torre de David, pues ya parece por lo hablado que el monte Moria és monte lleno de sacrificio, de oración, de prophecía, monte de doctrina, de misericordia y divinidad. [...] El monte Oliveto es en Judea, cabe la ciudad de Jerusalén [...]. Al pied deste monte nasce un río, el qual llaman torrente Cedrón y entre ambos está el huerto Gethsemaní donde Jesú, nuestro redentor, entró a orar por muchas vezes y le tomaron / 99c después los judíos.

\section{FIGURA 2}

\section{Jerusalén}

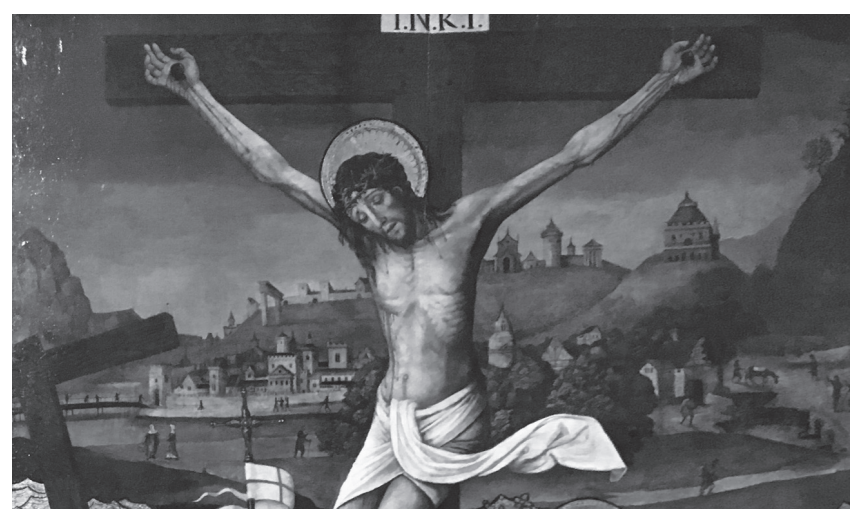

Es sabido que todas las obras que, descendientes de las Meditationes vitae Christi, tratan de conducir al ejercitante por caminos de contemplación no ahorran descripciones para estimular en el lector la imaginación donde todo es lícito excepto aquello que vaya en contra de la fe y de la moral. Siguiendo este criterio, la Vita Christi ${ }^{4}$ (VCC) de Ludolfo de Sajonia describe la ciudad de Jerusalén de la siguiente manera:

en los anaqueles de nobles, religiosos y eruditos a partir del siglo XVI. En esta obra se amalgaman la guía de viaje a Terra Santa, el relato del viaje del propio Breidenbach y la argumentación reivindicativa de la necesidad de unión de la Cristiandad frente a eventuales invasiones de pueblos no cristianos (cfr. Tena 1998, 1555-1562).

4 Esta obra es citada a partir de la traducción de Roís de Corella publicada el 1485 .
Jerusalem, ciutat de Déu e del món senyora, de la qual tantes maravelles han dit e scrit los sants patriarques e profetes. Al devallant de la montanya de la part de migjorn e de ponent stà situada. Té lo siti de la part de migjorn, al costat del mont de Sion, e de aquí devalla la longitut sua devers tremontana. Hi té de ponent lo mont de Sión, lo seu ample la volta de orient devalla fins al torrent de Cedron e a la vall de Josafat se declina. Stà lo siti de la ciutat en alt a la part de la tremontana hi en lo costat de ponent hi en la part de orient es per tot baixa, axí que.Is fems en temps de pluja, per la porta que dels Fems se nomena, al torrent de Cedron deva$\operatorname{llen}^{5}$ (VCC, 45v, b).

La composición vertical del cuadro sitúa el punto de vista bastante alto ya que, muestra en un primer plano, que coincide con el tercio superior de la tabla, la figura central: Jesús muerto en la cruz sobre el paisaje de la ciudad de Jerusalén; la figura del crucificado se alza sobre los otros personajes $y$, contrastando, se enmarca en un paisaje que representa, como se ha dicho, una visión idealizada de Jerusalén que en algunos aspectos recuerda una ciudad nórdica, exhibiendo una vegetación minuciosa donde se avistan casas con las típicas fachadas à pignon que apuntan a una posible influencia de la pintura flamenca siempre detallista y descriptiva. ${ }^{6}$ Igualmente se pueden observar construcciones y ruinas clásicas que aproximan esta tabla al maestro Paolo da San Leocadio (Reggio Emilia 1447- Valencia c.1520),

Es evidente, que en el encuadre de un calvario la cruz sea el elemento central pero, tal vez, situar al crucificado superpuesto a la ciudad de Jerusalén, apunte, en este caso, a la intencionalidad de poner de relieve la superioridad del sacerdocio de Jesucristo frente al sacerdocio levítico que simplemente prefigura el verdadero sacerdocio. Se proyecta la figura del Redentor - sacerdote y víctima - sobre la ciudad del templo. Podría tratarse de una superposición del cuerpo de Cristo sacrificado mediante el cual el lugar del sacrificio de la Antigua Ley -el templo de Jerusalén- queda substituido por el lugar del nuevo sacrificio: el mundo entero.

Aunque con su muerte, Jesucristo inaugura un sacerdocio nuevo, este hecho se produce en la ciudad santa, Jerusalén, para mostrar el vínculo con los periodos anteriores de la historia de la Salvación. De todos es sabido que la intervención de Jesucristo en la historia de la Salvación fue precedida por una serie de etapas preliminares que constituyen la historia Salvífica del Antiguo Testamento. Francesc Eiximenis, en el Primer del Crestià, ${ }^{7}$ lo explica de la siguiente manera:

La primera és per unitat de fe, car totes les tres Leys han creegudes unes matexes coses, qui són les principals en nostra crehença; no dich pas que haien cregut articles en egual nombre, car més n'à crehegut la Lig de Scriptura

Jerusalén, ciudad de Dios y señora del mundo de la cual tantas maravillas han dicho y escrito los santos patriarcas y profetas. Está situada en la ladera de la montaña en las partes de mediodía y de poniente. En la parte de mediodía junto al monte Sión y desde aquí desciende hacia el noroeste hasta el torrente Cedrón y valle de Josafat. Está situada en alto pero desciende en dirección este de tal manera que, en tiempo de lluvia, toda la basura de la ciudad desciende por la llamada puerta de la Basura hacia el torrente Cedrón (traducción del autor del artículo).

Sobre la influencia de los flamencos en la pintura valenciana del siglo XVI: Benito y Gómez (2001 y 2006) Ferrer y Ferrer (2016).

Ms 40, Arxiu de la catedral de València. 
que la Lig de Natura, e la Lig de Gràcia més que la Lig de Scriptura. Axí com les revelacions de nostre Senyor són estades més fetes segons que lo temps més anava avant, axí com appar en lo segon capítol, hon totes les tres Leys han creegut fermament que és hun Déu e aquell ésser creador de tot lo món e retribuïdor /170r,b nostre final. Car, segons que diu sant Pau, Ad Hebreos, capitulo Xıo, açò cové a creure ha cascú de necessitat qui ve a la fe cathòlicha. Ultra açò, cascuna d'aquestes tres leys han crehegut com a article necessari a salut dels hòmens, qui són estats en via de Salvació, e en aquelles tres Ligs, que hun hom devia venir en lo qual e per lo qual los hòmens del món aconseguirien Salvació ${ }^{8}$ (Eiximenis, Primer del Crestià 2, 199).

Francesc Eiximenis, seguidor ferviente de la división de la historia en periodos, se refiere a Jerusalén como vínculo de unidad entre ellos: ${ }^{9}$ "En aquesta matexa unitat [de l'Església] fon encara testimoni, unitat de la ciutat [de Jerusalem] e del loch en lo qual la dita unitat és sots Ley de natura consegrada, sots Lig de Scriptura altament conservada, sots Ley de Gràcia maravellosament declarada» ${ }^{10}$ (Primer del Crestià 2, 199).

El franciscano insiste en la simbología de la ciudad santa, como el lugar central de culto en las tres etapas de la historia de la Revelación. En la etapa de Naturaleza fue el lugar de encuentro entre Melquisedec y Abraham; y el lugar elegido para el sacrificio de Isaac:

Car deus saber que la unitat de la ciutat de Jerusalem és aquella mateixa ciutat, qui en temps de Natura estech per aquell maravellós Melchisedech, rey e sobiran sacerdot de Déu totpoderós, misterialment hedificada; ${ }^{11}$ e estech per lo gran e místich sacrifici de Abraam, gloriós patriarcha, altament en esperit consegrada e glorificada ${ }^{12}$ (Primer del Crestià 2, 199).

$8 \quad$ La primera es por unidad de fe, porque las tres Leyes han creído las mismas cosas que son fundamentales en nuestro credo; no digo que hayan creído el mismo número de artículos porque en más artículos ha creído la Ley de Escritura que la Ley de Naturaleza; y la Ley de Gracia más que la Ley de Escritura. Así como las revelaciones de nuestro Señor se hicieron según el tiempo avanzaba, así aparece en el segundo capítulo, donde las tres Leyes han creído firmemente que hay un solo Dios que es creador de todo el mundo y nuestro juez final. Porque, según que dice san Pablo, $A d$ Hebreos, capitulo $\mathrm{XI}$, esto conviene creer necesariamente a cada fiel de la fe católica. Además de esto, cada una de las tres Leyes han creído como artículo necesario para la salvación de los hombres que vendría un hombre por el cual el resto de hombres conseguiría la salvación.

9 Como ha dicho Lerner, el interés de Francesc Eximenis por la división de los tiempos aparece en numerosas ocasiones tanto en el Crestià, como en su Vida de Jesucrist. El franciscano establece tanto los tres estadios por los que ha transcurrido la Revelación como las siete partes en las qe se divide la historia de la Iglesia como una fuente para pronosticar el futuro, cfr. Lerner $(2006,22-23)$; Brines $(2004,404)$ nota 1580 .

10 De la unidad de la Iglesia fue testigo la unidad de la ciudad de Jersualén y del lugar en el cual dicha unidad fue consagrada en época de Ley de Naturaleza y altamente conservada bajo la Ley de Escritura y maravillosamente declarada en época de la Ley de Gracia.

11 El sacerdocio de Cristo, conforme era figurado por Melquisedec, sin padre ni madre ni genealogía $(\mathrm{Hb} 7,3)$, es un sacerdocio eterno (Hb 5,6; 6,20; Hb 7,17.21), para siempre ( $\mathrm{Hb} \mathrm{7,3;} \mathrm{Hb} \mathrm{7,25).} \mathrm{Jesús,} \mathrm{en}$ tanto que permanece para siempre, tiene un sacerdocio perpetuo $(\mathrm{Hb}$ $7,24)$; siempre vivo para interceder por los hombres (Hb 7,25). Sin embargo, su sacerdocio, su inmolación, tuvo lugar una sola vez ( $\mathrm{Hb} 9,11$ 14, 26-28). Y por tanto su muerte, con su propia sangre, selló el Nuevo Testamento; y por eso es el mediador de la Nueva Alianza (Hb 9,15).

12 Porque debes saber que la unidad de la ciudad de Jerusalén es
Jerusalén también fue la ciudad elegida en tiempos de Escritura:

Aprés, aquella ciutat e loch estech per nostre Senyor Déu elegit, així com a special habitació ordenada e de tot lo món singularment eleta a ésser cadira principal en doctrina de $/ 171$ r,a sciència de la lig escrita e en coronació dels reys, e en domicili dels sobirans bisbes e «en temple a Déu singularment de tot lo món elet a fer los sants sacrificis a salabració de la sua lahor per los legals sacerdots e levites» ${ }^{13}$ (Primer del Crestià 2, 199).

Se ha comentado anteriormente que, en la tabla de Macip, la figura del crucificado sobresale de la ciudad de Jerusalén tal vez con una intención didáctica que pretenda explicar el sacrificio de Cristo como una recapitulación de toda la historia de la Salvación y se haya elegido la vista sobre la ciudad de Jerusalén precisamente para poner de relieve el vínculo entre todos los periodos de historia de la Salvación. Dice Francesc Eximenis al Primer del Cristià.

Per què, plach al Senyor beneyt, per ensenyar la damunt dita unitat de una Església per aquesta unitat de loch, aquí mateix primerament fundà la sancta Religió xrestianna e açò primerament honrà la ciutat, dita vila e loch, per la sua sancta preycació e per la sua alta virtut ensenyada en còpia e multitut de miracles infinits axí mateix per la sua mort sagrada que aquí li plach pendre ${ }^{14}$ (Primer del Crestià 2, 199).

E encara li plach aquí trametre lo Sant Esperit en lo çenacle, hon havia instituhida la consecració del seu preciós cors, e volch que los sants apòstols aquí mateix preycassen la veritat de la santa fe xrestiana, e volch que fos consegrat per la sanch d'alguns dels primers fundadors dels xrestians, aprés, ací mateix; axí de sanct Jacme menor, bisbe de aquella matexa ciutat; de sanct Esteve gloriós e prothomàrtir e de molts altres qui serien lonchs de comptar ${ }^{15}$ (Primer del Crestià 2, 199).

Finalmente, Eiximenis justifica la elección de Jerusalén como símbolo en favor de la unidad de la fe Católica. «Per les quals coses appar com lo Senyor nos ensenya figuralment «la unitat de aquesta sancta Església, per la qual unitat de aquest loch» que axí elegí hun mateix com a radical

aquella misma ciudad, que en tiempos de Naturaleza estuvo misteriosamente edificada por aquel maravilloso Melquisedec, rey soberano y sacerdote todopoderoso; y estuvo consagrada y glorificada por el sacrificio místico de Abraham, glorioso patriarca.

13 Después, aquella ciudad estuvo elegida por Dios, nuestro Señor, como especial habitáculo y singularmente elegida para ser la cátedra principal en la doctrina y ciencia de la Ley escrita y lugar de coronación de los reyes y domicilio de los líderes religiosos y templo elegido especialmente por Dios para realizar los sacrificios propiciatorios en su honor por los sacerdotes del antiguo Testamento y levitas.

14 Porque le pareció bien al Señor bendito, para ensenyar la unidad de la Iglesia por esta unidad de lugar, aquí mismo primeramente fundó la santa religión cristiana y, para esto, primeramente honró la Ciudad por su santa predicación y por su alta virtud ensenyada abundantemente y por la cantidad inmensa de milagros así com por su sagrada muerte que le pareció bien aceptar.

15 Y aún le pareció bien aquí enviar el Espíritu Santo al cenáculo, donde había instituido la consagración de su cuerpo precioso y quiso que los Santos Apóstoles aquí predicasen la verdad de la santa fe cristiana y quiso que fuese consgrada por la sangre de algunos de los primeros fundadores de los cristianos, después, aquí mismo; así de Santiago el Menor, obispo de aquella misma Ciudad; de sant Esteve glorioso protomártit y de muchos otros que sería largo de contar. 
d'aquestes tres leys beneytes, segons que appar per ço qui dit és» ${ }^{16}$ (Primer del Crestià 2, 199).

El Calvario de la Redención no trata de impresionar al espectador ni de provocarle sentimientos particulares de compasión sino de orientarlo hacia la meditación de uno de los artículos del dogma católico que expresa el símbolo del triunfo definitivo de Cristo sobre la muerte. ${ }^{17}$ Con el fin de meditar los misterios de la fe, muchos autores de literatura espiritual recomiendan al ejercitante que se represente mentalmente aquello que quiera contemplar. En esta acción, la libertad es ilimitada (cfr. Hauf 1990; 1998; 2000). El autor de Meditationes Vitae Christi dice al respecto que no todas las cosas que se pueden meditar sobre las enseñanzas y actuaciones de Cristo constan en el evangelio y que en su libro se contarán dichos y hechos que pudieran haber sucedido. Estas interpolaciones al texto evangélico tienen la finalidad de percutir sobre los afectos del orante para que, con la imaginación, pueda hacerse presente, como un personaje más, en la vida de Cristo. ${ }^{18}$

\subsection{Redención}

Según la doctrina católica, la vida, muerte y resurrección de Jesucristo se presentan íntimamente unidas para la salvación humana. El sacrificio propiciatorio del Hijo de Dios constituye el acto supremo de culto, infinitamente superior a todos aquellos de la antigua Alianza. Se trata de un sacrificio único y verdadero en el cual Cristo ha sellado la nueva Alianza con su propia sangre. ${ }^{19}$ Cristo es, al mismo tiempo y para siempre, sacerdote y víctima. De todo esto, y siempre siguiendo el dogma católico, se derivará una nueva creación y un nuevo Adán, Cristo es hijo de Adán y cabeza del género humano. Un nuevo hombre surge, entonces, porque todos los hombres, constituidos en unidad, forman el cuerpo místico de Cristo que es la Iglesia. Al tratar del sacerdocio de Cristo en lo relativo a la Redención, la Carta a los Hebreos dice:

16 Por lo cual parece como que el Señor nos enseña, por medio de una figura, la unidad de esta santa Iglesia; por esta unidad de lugar que así eligió una misma raíz para las tres Leyes benditas, según parece por lo que se ha dicho.

17 De los comentarios que santo Tomás de Aquino - Lib. 3 d. 9 q. 1 a. 2 qc. 2 ad-y san Buenaventura - Lib. 3, d. 9, art. 1, q. 2- hicieron al Liber sententiarum de Pedro Lombardo, se pueden extraer algunas de las bases teóricas que, a partir del siglo XIII, contribuyeron a la integración de las imágenes devotas en la vida de piedad. Ambos autores coinciden en atribuir al arte religioso una triple función: explicar la doctrina a quien la desconoce, mover a devoción, y recordar los méritos de Cristo y de los santos. Es obvio que, en cualquier manifestación de arte devoto, estos tres elementos ni se manifiestan de manera simultánea ni presentan valor equivalente. Ahora bien, en la contemplación, la libertad para amplificar, interpretar y reinventar el texto evangélico es máxima y no tiene más límites que los impuestos por la doctrina y la moral.

18 Non autem credas, quod omnia quae ipsum dicisse vel fecisse constat, meditari possimus, vel quod omnia scripta sint: ego vero ad maiorem impressionem, ea sic, ac si ita fuissent, narrabo. (...) Tu autem, si ex his fructum sumere cupis, ita te praesentem exhibeas his quae per Dominum Jesum dicta et facta narrantur, ac si tuis auribus audires et oculis ea videres, toto mentis affectu diligenter delectabiliter morose omnibus alliis curis et sollicitudinibus omissis (MVC, 1868, XII: 511).

Cfr. Vanhoye (1980). También se puede rastrear el sacerdocio de Jesucristo en el evangelio de Juan, Feuillet (1985) y Heil (1995).
Todo esto es un símbolo para el tiempo presente; pues las ofrendas y sacrificios que allí se ofrecen a Dios no pueden hacer perfecta la conciencia de los que así le adoran. [...] Pero Cristo ya vino, y él es ahora el sumo sacerdote de los bienes definitivos. El santuario donde actúa como sumo sacerdote es mejor y más perfecto. [...] Ha entrado una sola vez y para siempre, y ha obtenido para nosotros la salvación eterna. [...] Pues Cristo, por medio del Espíritu eterno, se ofreció a sí mismo a Dios como sacrificio sin mancha, y su sangre limpia nuestra conciencia de las obras que llevan a la muerte, para que podamos servir al Dios viviente $(\mathrm{Hb}$ 9,9-14).

Esta redención, hecha de una vez para siempre, alcanza también a toda la humanidad anterior a Cristo. Cuando Jesús, clavado en la cruz, expiró, no murió un simple hombre sino el mismo Hijo de Dios en su naturaleza humana. Su alma unida a su divinidad, separadas del cuerpo, acudieron al Sheol para liberar las almas de los justos allí detenidas. Este misterio recogido en el Credo apostólico, aludido en el Nuevo Testamento -Act 2,31; Rom 10,6-7; Eph 4,8-10; 1 Pt 3,18-20; Ap 1,18- es mencionado por numerosos Padres de la Iglesia ya desde el siglo II. Aparece en el siglo IV en el Símbolo de Aquileya y posteriormente a las profesiones de fe de los Concilios del Letrán IV y II de Lyon (cfr. Denzinger 1951, 16, 801, 852 respectivamente). La universalidad del sacrificio de Cristo, siendo él mismo el sacerdote queda expresado en la Vita Christi de Isabel de Villena (VCV):

Estant lo Senyor e Redemptor nostre en turment inrecomptable, tenint los ulls fermats en lo Cel, rahonantse secretament ab lo seu Pare eternal, suplicava aquell per la nostra redemptio. Apres de una gran peça senti sa clemencia que lo seu Pare era content dels treballs e penes que per natura humana havia sofert, e que no volia pus satisfacio del peccat de Adam, car copiosament bastava, lo que sofert havia a la redemptio del homens, encara que mil milia mons fossen poblats dels dits fills de $\operatorname{Adam}^{20}$ (VCV 2, 402).

El desarrollo teológico de la Redención humana por la pasión, muerte y resurrección de Cristo es, obviamente, recurrente en la literatura cristiana desde los mismos inicios del cristianismo hasta nuestros días. Para el cristianismo, el plan primitivo de la Creación había sido roto por la rebelión del pecado del hombre. Para su restitución, fue necesaria una nueva intervención de Dios que se realizó en la obra redentora de Jesucristo, Mesías e Hijo de Dios. El Cartujano compara el sacrificio de Cristo con una batalla a ultranza, en concreto con el enfrentamiento entre David - figura de Cristo- y Goliat que representa el mal:

O bellicós strenu cavaller hon tens les tues armes? Puix entres en la batalla, ab la fona dels ligams de les tues mans, ab les cinch pedres de les tues nafres, ab lo bastó de la creu has derrocat al jagant Golies e ab lo seu coltell, que era la sua pròpia malícia ab la qual la mort

20 Estando el Señor y Redentor nuestro en tormento inenarrable, teniendo los ojos fijos en el cielo y conversando secretamente con el Padre eterno, le suplicaba por nuestra redención. Después de un rato notó Su Clemencia que el Padre estaba contento de las penalidades que por la naturaleza humana había sufrido y que no quería más satisfacción del pecado de Adán, porque lo que había sufrido en la redención de los hombres copiosamente bastaba aunque miles i miles de mundos fuesen poblados por los hijos de Adán. 
te havia procurada, has degollat a ell. Vençuda la mort, que a tot lo món vençia, has despullat los inferns que a tot lo món despullaven ${ }^{21}$ (VCC, IV,73v,b).

\subsection{Gestualidad}

El Calvario de la Redención es un tema o razonamiento discursivo que representa la visión del cuerpo de Cristo en la cruz por parte de los habitantes del Sheol una vez producida la muerte redentora. Francesc Eiximenis, a la Vida de Jesucrist, ${ }^{22}$ lo explica de manera literaria y dice:

Capítol CXXIII. Qui mostra com lo Salvador devallà a delliurar los sants Pares. Quines coses fores fetes lavors en lo Infern. La primera que lavors tot aquell loch estech il.luminat de gran e fort bella lum; la segona que aytant tost los ensenyà la sua santa Divinitat, la qual jamés no·s separà de aquella santa ànima ne del seu preciós cors e de continent foren tots aquí mateix benahuyrats [...] la setena [...] que aquí mateix los preycà; [...] la deena diu que d'aquí pujà ab tota aquella santa companya al mont de Calvari, a instància dels Sants Pares, per ensenyar-los lo seu cors penjat en la creu, cor encara no era levat, del qual foren fort moguts de gran compassió [...]. E diu que ab sobirana reverència e diligència se acostaren tots qui eren innumerables al preciós cors de Jesucrist e tot quant hi havia tot o volien veure e demanar la rahó e causa al Senyor, axí com de la creu, dels claus e de les nafres e del nombre de aquelles. Altres guardaven la disposició del cors e de sos membres concordant les prophecies fetes d'ell e del seu cors e de la sua preciosa mort $a b$ ço que contemplaven en la sua gloriosa carn o persona. [...] la onzena que lo Rey de glòria de aquí partint parlà familiarment a la sua santa mare e féu que ella, arrapada en sperit, veu a ell e a tota aquella multitut gloriosa ${ }^{23}$ (VCE 9, 123, 337,b).

Si se considera la composición visual de Macip a la luz de este texto de Eiximenis, sería necesaria la diferenciación de dos mundos: el espiritual y el material. Al mundo material pertenecen el cuerpo muerto de Jesús, la Virgen, san Juan

21 ¡Oh valeroso caballero! ¿Dónde tienes tus armas? Entras en la batalla con la honda fabricada con las ataduras de tus manos; con las cinco piedras de tus llagas. Con el bastón de la cruz has derrocado al gigante Goliat, lo has degollado. Vencida la muerte que a todos vencía has expoliado al infierno que a todos expoliaba.

22 La Vida de Jesucrist de Francesc Eiximenis (VCE) se cita a partir del ms 209 de la Biblioteca de la Universitat de València. Siempre se referencia la parte del libro, el capítulo y la página del citado manuscrito.

23 Capítulo 123. Que muestra como el Salvador bajó a librar a los Santos Padres. Qué coses fueron hechas entonces en el infierno. La primera que entonces todo aquel lugar se iluminó con una luz intensa y bella; la segunda que en el mismo momento en el que mostró su santa divinidad, la cual jamás se separó de su santa alma ni de su precioso cuerpo, alcanzaron la bienaventuranza; [...] la séptima que aquí mismo les predicó [...] la décima dice desde aquí subió con toda la santa compaña al monte Calvario, a instancia de los Santos Padres, para enseñarles su cuerpo que pendía en la cruz, porque aún no lo habían quitado, de lo cual fueron movidos a gran compasión. [...] Y dice que con soberana reverencia y diligencia, todos aquellos, que eran una multitud innumerable, se acercaron al precioso cuerpo de Jesucristo y de todo cuanto veían preguntaban la causa, tanto de la cruz como de los clavos y de las heridas y su cantidad. Otros miraban la disposición del cuerpo y de sus miembros que concordaban con las profecías hechas de él y de su cuerpo y de su preciosa muerte con lo que contemplaban en su cuerpo glorioso; [...] la undécima que el Rey de Gloria marchándose de aquí habló familiarmente a su santa madre e hizo que ella, en un arrobo, contemplase tanto a él como a la multitud gloriosa.
Apóstol y María Magdalena. El resto de personajes forma parte del mundo espiritual, es decir: el mismo Jesucristo alma de Jesucristo-, y los justos que lo precedieron en la muerte y han sido rescatados por él. Parece que el artista haya seguido también las palabras de sor Isabel de Villena. La abadesa del monasterio de la Trinidad, al escribir, en su Vita Christi, el encuentro de Jesucristo con las almas del Limbo, exhorta, como en tantas otras ocasiones a lo largo de su obra, al uso de la imaginación: ${ }^{24}$ "E ab tot que en aquest acte no.y hagues res corporal, ans eren tots sperits sens res de humanitat, devem pensar que tots eren aquí en forma humana, per donar orde a la nostra piadosa contemplació, car per les coses corporals venim en coneixença de les espirituals» ${ }^{25}$ (VCV 3, 6).

Dentro del cuadro de Macip, en el grupo de las almas del Limbo, se observa una figura que, vestida con un manto de color carmesí y con el lábaro de la resurrección, representa el alma de Cristo que unida a su divinidad conduce a los justos a contemplar su cuerpo, que todavía colgando en la cruz, muestra las heridas abiertas por los tormentos de la Pasión. La separación del cuerpo y del alma de Cristo quedan unidas por la divinidad. Francesc Eiximenis lo expresa así: «Passat lo Salvador d'esta vida tantost les tres jerarchies de Paradís, qui ja eren aquí esperants lo seu passament, lo adoraren ab la major reverència que pogueren, ço és, a la sua santa ànima unida ab la sua santa divinitat» ${ }^{26}$ (VCE, 9,117).

Francesc Eiximenis toma una postura antinestoriana ya que reconoce, con el sentir tradicional de la Iglesia Católica, ${ }^{27}$ que la divinidad tampoco abandonó nunca el cuerpo de Cristo: "La segona que aytant tost los ensenyà la sua santa Divinitat, la qual jamés no.s separà de aquella santa ànima

24 Todas les citas de la Vita Christi d'Isabel de Villena (VCV) proceden de la edición de Miquel i Planas (1916) y se referencian atendiendo al volumen y página.

25 Y aunque en este acto no había nada corporal, antes bien eran todos espíritus sin nada humano, debemos pensar que todos estaban aquí en forma humana, para dar orden a nuestra piadosa contemplación, porque por las cosas corporales llegamos al conocimiento de las espirituales.

26 En el mismo instante del paso del Salvador de esta vida a la otra, las tres jerarquías del Paraíso, que ja esperaban su traspaso, lo adoraron con la mayor reverencia que pudieron, es decir, a su santa alma unida a su divinidad.

27 Cuando Jesús, clavado en la Cruz, expiró, no murió un simple hombre: murió Dios; murió el Hijo de Dios en su naturaleza humana. Esta primera observación, opuesta a los nestorianismos de todos los tiempos, tiene su importancia. Al entregar Cristo su espíritu, Dios experimentó la muerte humana, porque aquel cuerpo destrozado era su cuerpo y el alma que entregó era su alma. La naturaleza humana del Señor no es un assumptus homo, sino la humanidad de Dios, subsistente por y en el ser divino de la Persona del Verbo. Por tanto, esa humanidad es como un modo de ser de Dios: el modo de ser no divino que el Hijo de Dios tomó para Sí. [...] Por lo que se refiere al cuerpo muerto del Señor, algunos Padres opinaron que fue abandonado por la divinidad. Sin embargo, sobre todo a partir de San Gregario Niseno, prevaleció la afirmación de que la Persona divina continuó unida al cuerpo muerto de Cristo. Esto confiere a la muerte de Jesús un rasgo peculiar, propio, que no se da en la de ningún hombre: en ésta, el alma es despojada del cuerpo y éste deja de ser un cuerpo humano; la corrupción del cadáver, de hecho, no es más que el desarrollo de un proceso iniciado en el mismo instante de la muerte. En Cristo, por el contrario, no fue así: la Persona del Verbo experimentó no sólo el modo de ser del alma separada -despojada de su cuerpo-, sino que experimentó también el modo de ser inanimado de un cuerpo sin vida. En este sentido, Dios sufrió nuestra muerte más plenamente que los hombres (Ocáriz 1982, 751 y ss.). 
ne del seu preciós cors e de continent foren tots aquí mateix benahuyrats» (VCE 9, 123). Por tanto, en el Calvario de la Redención de Vicent Macip aparecen representados el cuerpo, el alma, la sangre y la divinidad de Cristo.

Se ha mencionado anteriormente que el Calvario de la Redención es un tema o discurso que pertenece al ciclo de Pasión y que expresa la exhibición de Jesús muerto en la cruz a aquellos que estaban retenidos en el Sheol esperando que el sacrificio de la Nueva Alianza abriera para siempre las puertas del cielo. Sitúa la historia de la Salvación en el punto más importante: Jesucristo ha expirado y su muerte ha abierto definitivamente la puerta del Cielo a todos: Una enim oblatione, consummavit in sempiternum sanctificatos (Hb 10,14). Se trata del quinto artículo del Credo apostólico: descendit ad inferos. El concepto inferos se puede entender de diferentes formas. Ludolfo de Sajonia, en el Vita Christi, explica la división del inframundo de la siguiente manera:

Infern, per lo loch, en quatre maneres se troba. Primerament lo centre de la terra hon los inichs damnats, eternament cruciats, vivint, morir desigen. Sobre aquest infern stà lo loch hon stan aquells qui, no per peccats que ells hagen posat en obra mas per lo peccat original, són privats de la beatifica vista de la divina essència; de la qual privació no senten pena, puix no $\mathrm{u}$ han perdut per culpa de ses obres. Sobre aquest loch és lo purgatori, hon comunament les ànimes, les penes temporals en grans dolors purguen. Sobre aquest purgatori staven los Sants Pares, en lo loch que lo Si d'Abraam se nomena, perquè fon pare e principi de la fe en lo judaich poble, e de les promeses del Messies. Ací devallà la sacratíssima ànima del Senyor e Déu nostre. E-ncara, rahonablement se deu creure que per alegria de la sua venguda, totes les ànimes de purgatori féu delliures e manà que al Si de Abraham pujassen donantlos la glòria ${ }^{28}$ (VCC, IV,77v, b).

Los personajes del cuadro de Macip están inmersos en un ambiente tranquilo y sereno, ocupados en un coloquio silencioso hecho de gestos y de miradas. Se trata de un grupo formado por personajes de diferentes épocas que viene a resaltar lo que representa la muerte redentora de Cristo para toda la historia de la humanidad y su presencia queda enfatizada por la representación del alma de Jesucristo, como mediador entre el hombre y Dios Padre: «Tornant a la història evangèlica: spirant lo Senyor a hora de nona, stigué lo cors en la creu y la sua ànima devallà a les infernals claustres per delliurar les ànimes santes que lonch temps passava que ab desig inefable a ell, Déu redemptor, speraven ${ }^{29}$ (VCC, IV,77v,a).

28 El concepto Infierno se puede en cuatro acepciones. Primeramente, como centro de la tierra donde los condenados viven en eterno tormento deseando morir. Sobre este infierno está el segundo Infierno donde están aquellos que están privados de la visión de la divina esencia no por sus pecados sino por el pecado original; de esta privación no tienen pena puesto que no la han perdido por su culpa. Sobre este lugar está el Purgatorio, donde las almas purgan con grandes dolores las penas temporales. Sobre este Purgatorio estaban los Santos Padres, en el lugar llamado Seno de Abraham porque fue el padre y principio de la fe en el pueblo judío y de las promesas del Mesías. A este lugar, bajó la santísima alma del Señor y Dios nuestro. Y aún se debe creer razonablemente, que con su llegada a este lugar liberó a todas las almas del purgatorio y mandó que subiesen al Seno de Abraham dándoles la gloria.

${ }_{29}$ Volviendo a la historia evangélica: expirando el Señor a hora nona, estuvo su cuerpo en la cruz y su alma bajó al Infierno para librar
El perizonium flotante, siguiendo el esquema de los primitivos flamencos, contrasta, por simetría con el lábarum de la Resurrección. Ambos objetos ponen de relieve los únicos personajes - el alma de Jesús y Juan Bautista- que no miran a la cruz de hito en hito aunque la señalan con el dedo índice, entrando en contacto visual con algún otro personaje con quien muestran contraste conceptual (Fig. 3).

\section{FIGURA 3} Juan Bautista y Zacarías

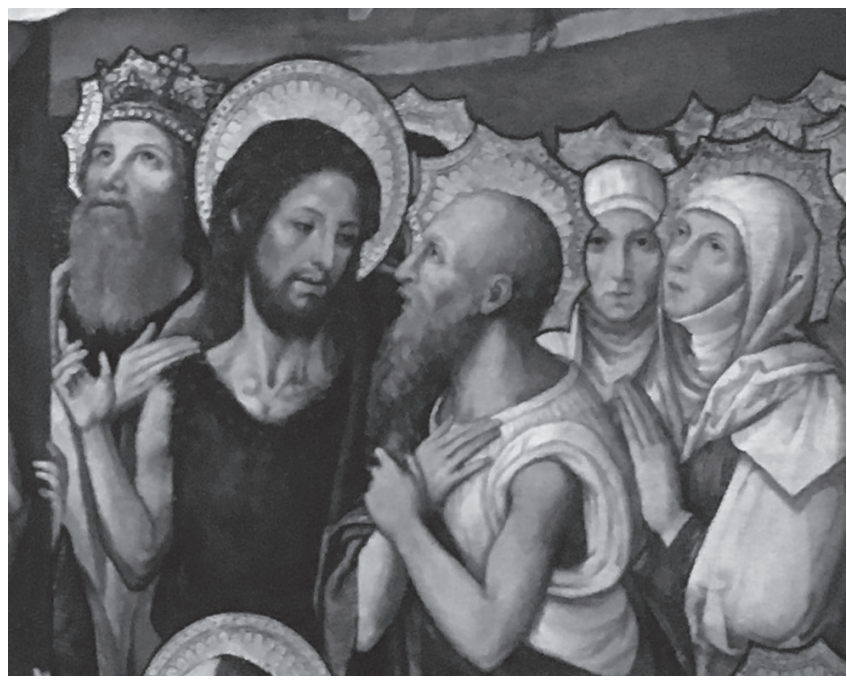

Juan Bautista, vestido con pieles y nimbo redondo, parece hablar con un personaje del antiguo testamento que se podría identificar con su padre, Zacarías quien en la segunda parte del Benedictus (Lc 1,68-79) profetiza el papel que realizará su hijo, Juan el Bautista, en el plan de la Redención. EI Bautista es el eslabón entre el Antiguo y el Nuevo Testamento y señala el cordero de Dios entre los hombres mientras los profetas antiguos simplemente lo anunciaron. ${ }^{30}$ También aparece, con la cruz y nimbo redondo, el buen ladrón situado entre los padres del Limbo:

a las almas santas que, durante mucho tiempo, esperaban a su Dios y redentor con inefable deseo.

30 loannes quidam limes veteris et Novi Testamenti. Ideo et de senibus nascitur, et in utero exsultat. Zachariae os prius clausum, et post apertum. Videtur ergo loannes interiectus quidam limes Testamentorum duorum, veteris et novi. Nam eum esse, ut dixi, quodam modo limitem Dominus ipse testatur dicens: Lex et Prophetae usque ad loannem Baptistam. Sustinet ergo personam vetustatis, et praeconium novitatis. Propter personam vetustatis, de senibus nascitur: propter personam novitatis, in visceribus matris propheta declaratur. Nondum enim natus ad sanctae Mariae adventum, exsultavit in utero matris. lam ibi designatus erat, designatus antequam natus: cuius praecursor esset ostenditur, antequam ab eo videretur. Divina sunt haec, et mensuram humanae fragilitatis excedunt. Augustinus Hipponensis, Sermones, In natali loannis Baptistae, 293, 2. En efecto, Juan se asemeja a una especie de límite entre el Antiguo y el Nuevo Testamento. Que él es, en cierta manera, un límite, como acabo de afirmar, lo atestigua el mismo Señor al decir: La ley y los profetas llegan hasta Juan Bautista. Es, pues, la personificación de la antigüedad y el anuncio de la novedad. En atención a lo primero, nace de padres ancianos, y en atención a lo segundo, se muestra como profeta ya en el seno de la madre. Aun antes de nacer exultó de gozo en el seno de su madre ante la presencia de Santa María. Ya entonces se declaró; se declaró aun antes de nacer; aparece de quien es precursor antes de que le vea. Son misterios divinos que exceden la medida de la fragilidad humana. 
E lavors ell [el bon lladre] li dix: «Senyor, membre't de mi com vindràs en lo teu Regne!» E lo gloriós Salvador li respòs la dita quarta paraula, ço és, que per tot cert agués que, en aquell dia, ell seria ab Ell en Paradís. E·n aquell dia lo dit ladre veu la divinal essència unida ab la sua sancta ànima dins en lo loch on los sants pares eren, al qual, aquell mateix dia, lo Salvador devallà per salvar a ells ${ }^{31}$ (VCE 9,110, 131,b).

El buen ladrón aparece formando grupo con otros dos personajes que no muestran ningún atributo identificativo más que el nimbo polilobulado. Por el contexto de la Vida de Jesucrist de Francesc Eiximenis podrían ser identificados como Elías y Henoc que fueron arrebatados por el más allá sin pasar por la muerte. Los tres personajes son la presencia humana efectiva de la bienaventuranza por revelación tanto del Antiguo Testamento ( $G n 5,24 ; 2$ Re 2,11) como del Nuevo (LC 23,39-43). Se ha mencionado anteriormente la división de la historia de la Salvación en tres periodos: naturaleza, escritura y gracia. Eiximenis explica la misión atribuida a los dos personajes del Antiguo Testamento situándolos en el periodo correspondiente.

Per ajudar a la veritat de la santa fe e religió cristiana e per poderosament confondre la gran falssia e orribla nequicia d'aquell malvat anticrist trametrà, Jesucrist, Fill de Déu, lavors dos excel·lents barons qui ara són per ell reservats en vida corporal e espiritual en Paradís terrenal appel·lats Elies e Enoch. Aquell Enoch hi és per testimoni de la lig de natura /437v,a e Elies és per la lig de Scriptura ${ }^{32}$ (VCE 10,52, 347b).

El alma de Jesús, señalando la cruz, establece contacto visual con uno de sus tipos del Antiguo Testamento: Adán (Ro 5,15; 1Co 15,45). Así, esta pareja contrasta la rebelión de Adán y la sumisión de Cristo $^{33}$ (Fig. 4).

Consummatum est! son, siguiendo el evangelio (Jn $19,30)$ las últimas palabras de Jesús antes de expirar en la cruz. Con ellas indica que se ha cumplido la voluntad de Dios Padre y que la Redención se ha llevado a término.

La terça paraula que lo Salvador dix en la creu, sí, fon aquesta: Consumatum est! E volch dir, segons que diu sent Agostí, que acabat era lo misteri e procés de la nostra Redemptió, e les figures e prophecies e cerimònies fetes en la vella lig, e tot ço que lo Pare celestial avia manat fer al seu Fill per la nostra salvació. Per què d'aquí avant no restava sinó amar al seu Pare d'on havem forma de servar veritat en ço que prometem axi com lo Salvador qui les promissions fetes als pares e les

31 Y entonces el buen ladrón le dijo: "Señor, acuérdate de mi cuando llegues a tu Reino». Y el glorioso Salvador le respondió la mencionada cuarta palabra, esto es, que estuviese totalmente seguro que en aquel mismo día, estaría con Él en el Paraíso. Y en aquel día dicho ladrón vio la divina esencia unida a su santa alma dentro del lugar donde los Padres estaban y al que el Salvador bajó aquel mismo día.

32 Para ayudar a la verdad de la santa fe y religión cristiana y para confundir poderosamente la gran falsedad y horrible maldad de aquel malvado anticristo, Jesucristo Hijo de Dios, enviará entonces a dos varones excelentes Ilamados Elías y Henoc que están en cuerpo y alma en el Paraíso. Aquel Henoc está como testigo de la Ley de Naturaleza y Elías está por la Ley de Escritura.

33 Al tratar sobre la Encarnación del Hijo de Dios en su Vida de Jesucrist, Eiximenis dedica un capítulo especial a Adán: Capítol quart. Qui mostra com fo axí mateix revelat a Adam lo dit aveniment de Jesucrist (VCE 2,4). revelacions fetes als prophetes totes les ha complides en la sua preciosa mort ${ }^{34}$ (VCE 9,109, 330v, b).

FIGURA 4 Jesucristo y Adán

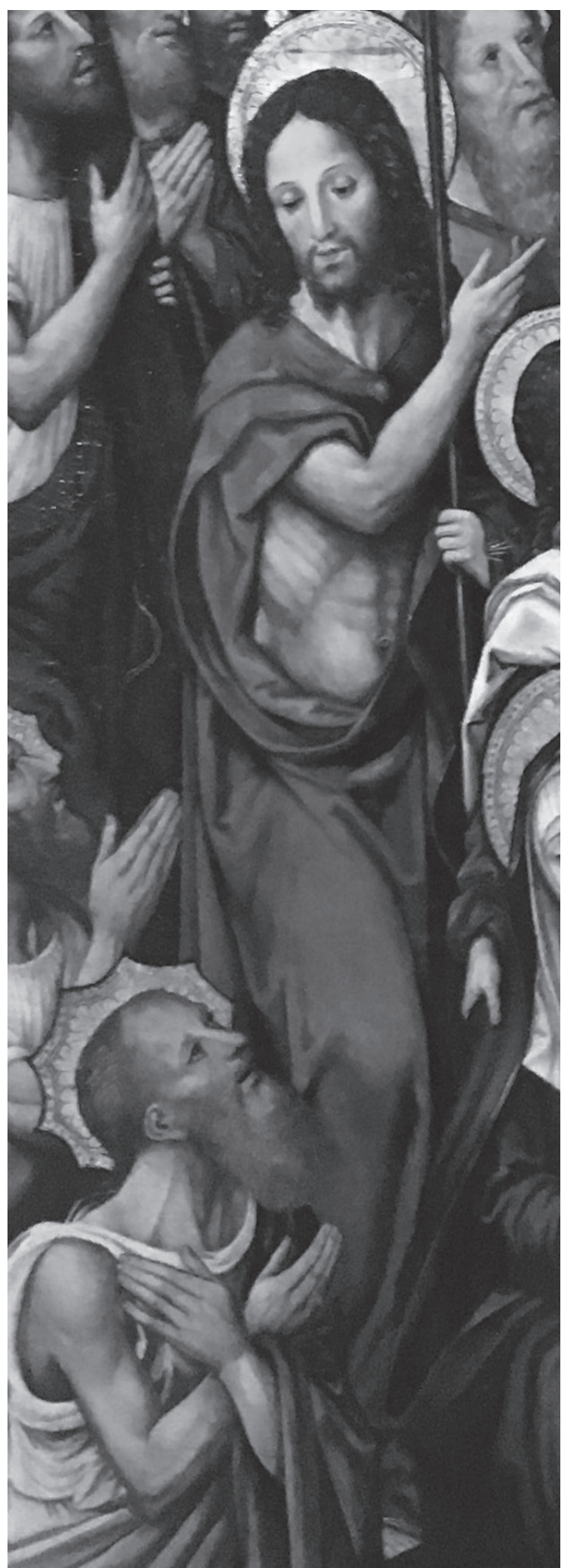

34 La tercera palabra que el Salvador dijo en la cruz fue: iConsumatum est! Y quiso decir, según que dice san Agustín, que el misterio y proceso de nuestra Redención se había cumplido: las imágenes, las profecías, las ceremonias hechas en la Ley antigua, y todo lo que el Padre celestial había mandado hacer a su Hijo por nuestra salvación. Por lo que de ahí en adelante no restaba sino amar a su Padre de donde tenemos forma de guardar la verdad en lo que prometemos así como el Salvador que ha cumplido, en su preciosa muerte, las promesa hechas a los Padres y las revelaciones hechas a los profetas. 
Dice el evangelio que con la muerte de Jesús el velo del templo que guardaba el misterio se desgarró de arriba abajo. Eiximenis lo explica así:

Quartament aprés lo passament del Senyor estech fet que la gran cortina que estava en lo temple de Déu e.I mig del Sancta sanctorum e del loch on cantaven los sacerdots estech fes per lo mig e tirat de cada part fins a la porta del temple. E com la dita cortina cobrís lo Sancta sanctorum axí que no.s podia veure per aquells qui estaven de la altra part de la cortina, emperò lavors aparech tot lo Sancta sanctorum clarament a tothom; e ço que estava dins amaguat axí com l'archa de Déu e.Is cherubins e.l altar del encens. E açò estech fet per dar a entendre que pus que ço qui era significat per les dites coses era acabat e manifestat al món, ço és, la Redemptió humana feta per la preciosa mort de Jesucrist qui d'aquí avant la dita cortina que significava com la dita Redemptió era amaguada no devia pus aquí estar ans devia cessar ${ }^{35}$ (VCE, 9,121, 336a).

Atendiendo a la palabra redención -etimológicamente, volver a comprar - se puede intuir una refundación, una renovación. De la resurrección de Cristo, se formó la Iglesia triunfante y militante. En el cuadro, se han podido identificar un pequeño grupo de justos, la multitud de nimbos polilobulados indica la incorporación, a la Iglesia triunfante, de los justos previos a la muerte de Jesús. El Cartujano lo expresa de la manera siguiente: «E axí com del primer Adam dormint se formà la sua muller, Eva, gentil, neta, graciosa e bella, axí del segon Adam, mort en la creu, però quasi dormint per la resurrectió presta, se formà la sua sposa bella, sens màcula ni ruha, la santa cathòlica Sgleya» ${ }^{36}$ (VCC, IV, $65 v, a)$.

Los versículos 5-11 del segundo capítulo de la carta de san Pablo a los Filipenses recogen un himno cristológico en el que se identifica a Jesucristo con el nuevo Adán, el hombre sobre quien todo se ha renovado. Dice Eiximenis:

Cor axí com los jueus, maliciosament, lo difamaren de molts e de grans crims falsament, axí plach al seu Pare que tanta sia la reverència que sia feta al seu sant nom, que qui•l hoirà nomenar en lo cel e en la terra o en lo abís infernal que de continent se ajenoll e confés de bocha que nostre senyor Jesucrist és ver Déu e seu a la dreta part de Déu lo Pare ${ }^{37}$ (VCE, 9,117, 334a).

35 Cuartamente, después de la muerte del Señor sucedió que la gran cortina que estaba en el templo de Dios entre el Sancta sactorum y el lugar donde cantaban los sacerdotes se desgarró por la mitad hasta la puerta del templo. Y como dicha cortina cubriese el Sancta sanctorum del tal modo que aquellos que estuviesen al otro lado no lo pudiesen ver, a partir de aquel momento y lo que estaba escondido de todos así como el arca de Dios y los querubines y el altar del incienso se pudo contemplar por todos. Y esto sucedió para dar a entender que lo que estas cosas significaban se había acabado y la Redención humana hecha por la preciosa muerte de Jesucristo se había manifestado al mundo, es decir, que de ese momento en adelante dicha cortina significaba la redención era apartada y no debía permanecer sino cesar.

36 Y así como del primer hombre, Adán, durmiendo se formó su mujer, Eva, gentil, limpia, graciosa y bella; así, del segundo Adán, muerto en la cruz pero como dormido por la presta resurrección, se formó su esposa bella, sin mancha ni arruga, la santa Iglesia católica.

37 Porque así como los judíos, maliciosa y falsamente lo difamaron de muchos y graves crímenes, así le pareció bien a su Padre que tanta sea la reverencia que sea hecha a su santo nombre que quien lo oirá en el cielo y en la tierra o en el abismo infernal que inmediatamente se arrodille y confiese con su boca que nuestro señor Jesucristo es verdadero Dios y está sentado a la derecha de Dios padre.
Para que al nombre de Jesús toda rodilla se doble en los cielos, en la tierra y en el abismo (Flp 2,10). Estos versículos evocan el contraste entre Jesucristo -Dios que se hace hombre- y Adán que siendo hombre tuvo la ambición de ser Dios. Eiximenis dice:

La segona és que plagué a la Santa Trinitat que solament la persona del Fill fos encarnada per estes rahons: la primera com l'om havia peccat desigant semblança de Déu e per consegüent havia dretament peccat contra lo Fill qui és ymatge e semblança del Pare. Al Fill, donchs, convenia que venjàs e relaxàs la injúria axí com aquell contra lo qual era specialment feta la ofensa. E aquesta rahó assigna sant Ancelm en lo seu Cur Deus homo $^{38}$ (VCE 3,8, 22v, a).

La obediencia de Cristo hasta la cruz repara la desobediencia del primer hombre. Dios Padre, al resucitar a Jesús y hacerlo sentar a su derecha, concedió a la humanidad poder manifestar la gloria de la divinidad que le correspondía. Todas las criaturas quedaron sometidas a su poder y los hombres tendrán que confesar la verdad fundamental de la doctrina cristiana que Jesucristo es el Señor, juez de vivos y de muertos.

Duos homines beatus Apostolus hodie retulit humano generi dedisse principium, Adam videlicet et Christum. [...] Factus, inquit, primus homo Adam in animam viventem, novissimus Adam in spiritum vivificantem. Ille primus ab Isto novissimo factus est, a quo est et animam consecutus ut viveret. [...] Hic est Adam, qui suam tunc in illo, cum fingeret, imaginem collocavit. Hinc est quod eius personam suscipit, nomen recipit, ne sibi quod ad suam imaginem fecerat deperiret. Primus Adam, novissimus Adam: ille primus habet initium, hic novissimus non habet finem, quia hic novissimus vere ipse est primus, ipso dicente: "Ego primus et ego novissimus ${ }^{39}$ (Pere Crisòleg, serm. 117).

Si se toma como marco conceptual la genealogía humana de Cristo, sería posible dar nombre a los personajes que aparecen en el cuadro sin ningún atributo identificador. Dentro de la multitud de santos pintada por Macip, en primer lugar, aparecen arrodillados, Adán y Eva, primera pareja humana, y Joaquín y Ana, abuelos de Jesús.

Siguiendo el iniciado marco conceptual, los dos personajes que, con nimbo polilobulado, aparecen detrás de la cruz de Cristo podrían ser identificados como Abraham y David. Cuando Eiximenis en la Vida de Jesucrist explica la Encar-

38 La segunda es que le pareció bien a la Santa Trinidad que solamente la persona del Hijo se encarnase por estas razones: la primera porque el hombre había pecado deseando parecerse a Dios y, consecuentemente, había pecado directamente contra el Hijo que es imagen y semejanza del Padre. Convenía, pues, que el Hijo vengase y relajase la injuria porque contra Él se había hecho especialmente la ofensa. Y por esta razón asigna san Anselmo en su Cur Deus homo.

39 Hoy relata el Apóstol que existen dos hombres desde el principio de la humanidad: Adán y Cristo. [...] El primer Adán, dice, como alma que vive, el nuevo Adán como espíritu vivificador. El primer Adán fue creado por el nuevo quien le concedió un alma para vivir. [...] El nuevo Adán colocó su propia imagen en aquel primer Adán que modeló. De aquí resulta que este primer Adán recibiera, del segundo Adan, tanto su naturaleza como su mismo nombre, para que aquel a quien había formado a su misma imagen para que no se perdiese quien había creado a su propia imagen. El primer Adán es el último Adán: el primero tiene inicio y el segundo no tiene fin, porque el nuevo Adán dijo: «yo soy el Primero y el último». 
nación del Hijo de Dios les dedica un capítulo especial: Qui mostra com en special estech revelat a Abraam e a Daviu per grans promissions y nos dice el franciscano:

Segonament promés esta cosa mateixa a Daviu dient-li, segons que legim Psalmo 131 De fructu vestris tui ponam super sedem tuam, ço és, que d'ell exirà qui siurà sobre la cadira, ço és, en la altea divinal, significada per la cadira de Daviu. E aquest és Jesucrist qui seu a la dreta part de Deú lo Pare, axí com legim Mathei, Ultimo. Sent Pau, Ad hebreos, sexto, fa special menció de la primera promissió feta a Abraam dient que nostre Senyor Déu jurà a ell esta cosa per dues coses immobles en veritat, en les quals no pot caure falsia, ço és, per si mateix qui és font de veritat e per lo seu consell eternal qui és immutable, dient Daviu, Consilium Domini in eternum permanet. E vol dir que ço que ha Déu eternalment proposat de ferm està no y cal negun duptar. $E$ d'aquest iurament fet per Déu a Abraam en esta materia, dix, Zacharies pare de sent Johan Baptista, segons que legim Luce, primo lusiurandum quod iuravit ad Abraam etc. E vol dir que la incarnació del fill de Déu se havia a fer per verificar lo jurament que nostre senyor Déu havia fet Abraam $^{40}$ (VCE 2, 7, 18a).

El canto de Zacarías (LC 1,68-79) resume la historia de la salvación en tres puntos: la alianza que convertiría Abraham en padre de una estirpe innumerable de fieles; la promesa a David que de su linaje surgiría el Redentor; y, finalmente, la Nueva Alianza en Cristo. Esta lectura permite dar nombre a los personajes que rodean la cruz: Abraham, con barba tupida, el rey David, con corona y Zacarías, el interlocutor de Juan el Bautista, junto a su esposa Isabel pariente de la Virgen que remite de nuevo a la genealogía humana de Cristo.

Obviamente, la tabla titulada El Calvario de la Redención tiene por centro el crucificado, no solamente porque esté situado en medio del cuadro sino porque tanto los gestos como las miradas de los personajes confluyen sobre él, exceptuados los casos del alma de Jesús que mira a Adán; la Virgen que no mira a ninguna parte; Juan el Bautista que mira a Zacarías; y dos mujeres de la multitud que miran al espectador de hito en hito.

Poco puede decirse de las dos mujeres anónimas que, adornadas con un nimbo polilobulado, miran al espectador. En cambio, la Virgen presenta una gestualidad en la que todo indica una actitud introspectiva tanto por los ojos semiabiertos que parece que no miren a ninguna parte; como por la postura corporal, de espaldas a la escena principal; como por la disposición de los brazos que parecen dibujar

40 En segundo lugar prometió esto mismo a David diciéndole, según leemos, Psalmo 131, De fructu vestris tui ponam super sedem tuam, esto es, que de él saldría quien se sentaría en el trono, esto es, en la altura divina significada por el trono de David. Y este es Jesucristo que sede a la derecha de Dios Padre, así como leemos Mathei, Ultimo. San Pablo, ad Hebreos, sexto, menciona especialmente la primera promesa hecha a Abraham diciendo que nuestro señor Dios le juró esto por dos cosas inamovibles en verdad, en las cuales no puede caer en falsedad, esto es, por sí mismo, que es fuente de verdad y por su consejo eterno que es inmutable, diciendo David: Consilium Domni in eternum permanet. $Y$ quiere decir que lo que ha propuesto Dios eternamente en firme está y no es necesario dudar. $Y$ de este juramento hecho por Dios a Abraham en esta materia, dice, Zacarías, padre de san Juan Bautista, según que leemos, Luce, primo: Iusiurandum quod iuravit ad Abraam etc. Y significa que la encarnación del Hijo de Dios se tenía que realizar para verificar el juramento que nuestro señor Dios había hecho a Abraham. un círculo. Aunque san Juan Apóstol posa su mano sobre ella, no muestran mantener contacto visual.

El alma de Jesús y Juan el Bautista muestran la palma de la mano - símbolo de sinceridad-que además, en ambos casos, la mano derecha, la mano de las buenas acciones, con la cual señalan a Cristo muerto. ${ }^{41}$ Este gesto, además de función deíctica, indica postura de diálogo, acentuado en este caso por la mirada, cada uno de los dos mira a su interlocutor con una actitud comunicativa.

Se ha dicho más arriba que la ausencia de contacto visual entre los personajes representados puede inducir a pensar que se trata de mostrar la oración dentro del cuadro, exactamente igual que las pinturas flamencas en las que por influencia de la Devotio moderna los personajes en oración quedan representados dentro de la obra de arte sin ningún tipo de enlace gestual (Panofsky 1953).

De la observación atenta de las manos, se puede concluir que la mayoría de los personajes mantienen unidas las palmas de las manos en señal de plegaria; Adán y Zacarías muestran las manos cruzadas, con las palmas abiertas, sobre el pecho cosa que indica aceptación y disponibilidad. La mano de san Juan Apóstol sobre la Virgen indica protección, compartir el dolor; en cambio, las manos abiertas de María Magdalena indican disponibilidad y aceptación. Mientras que las manos de la Virgen cerradas en sí mismas indican una actitud contemplativa, es decir todo lo ve dentro de ella misma.

Quizás se podría relacionar el gesto de las manos que aparecen en esta tabla - juntas, plegadas sobre el pecho o entrecruzadas - con las fases de la plegaria conducentes a la contemplación. Se podría relacionar la disposición de los brazos cruzados sobre el pecho con la meditatio; por otro lado, la disposición de las manos juntas con la oratio; y las manos entrecruzadas de la Virgen con la comtemplatio ${ }^{42}$ (Fig. 5).

41 «Ultra tots los dits privilegis ne posen dos los sants altres molts, ço és, que ell ha Jesucrist Batejat, [...] aprés ha a Jesucrist demostrat ab lo dit...» (VCE 3,119, 99v, b).

42 A principios del siglo XII, Guigo el Cartujo (†1118) escribió Scala claustralium o Scala Paradisi cuyo segundo capítulo explica la metodología para llegar a la contemplación. El sistema está dividido en cuatro fases: lectio, meditatio, oratio y contemplatio. Son cuatro escalones interrelacionados y basados en la lectio divina, es decir, la lectura sistemática de la Sagrada Escritura, cuando sobre el fragmento leído se establecen las causas, efectos y finalidades se llega a la meditatio, que si se convierte en petición se transforma en oratio, tercer escalón. En cambio, la contemplatio es una salida de las propias fuerzas y, por tanto, es un don de Dios: Est autem lectio, sedula Scripturarum cum animi intentione inspectio. Meditatio, est studiosa mentis actio, occultae veritatis notitiam ductu propriae rationis investigans. Oratio, est devota cordis intentio in Deum pro malis amovendis, et bonis adipiscendis. Contemplatio, est mentis in Deum suspensae elevatio, aeternae dulcedinis gaudia degustans (Colledge y Walsh 1970, 84). Para Guigó, la base de la vida interior radica en la lectio divina pero los cuatro escalones de su scala están interrelacionados: la lectio sin la meditatio es infecunda; la meditatio sin lectio puede conduir al error; la oratio sin meditatio es fría; meditatio sin oratio no consigue ningún efecto; contemplatio sin oratio es bastante rara (Baier 2009, 332). Ex his possumus colligere: quod lectio sine meditatione arida est; meditatio sine lectione, erronea; oratio sine meditatione est tepida; meditatio sine oratione, infructuosa: oratio cum devotione contemplationis acquisitiva; contemplationis adeptio sine oratione, aut rara, aut miraculosa (Colledge y Walsh 1970, 84). 
FIGURA 5

Posición de las manos

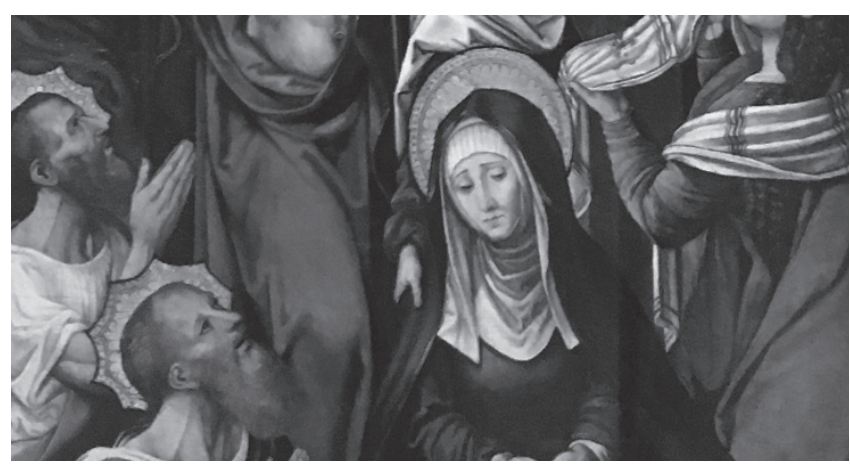

También, vinculado a la gestualidad, se puede observar que todos los personajes aparecen de perfil, excepto Cristo, su madre y Juan Bautista. Podría entenderse que la mayor dignidad queda expresada con la vista frontal de la cara en contraposición a la sumisión del perfil. Tal vez se haya elegido el perfil para significar el pecado original en el que todo ser humano nace excepto, por especial privilegio, la Virgen, concebida sin pecado, y san Juan Bautista que fue absuelto de él antes de su nacimiento.

Lo seté privilegi és cor dins lo ventre de sa mare, (Joan Baptista) fon purgat del peccat original, e açò com fon sanctificat per lo aveniment de Jesucrist a ell, ço és, quant la gloriosa visità a Elisabet, segons dit és. E diu açí un doctor que no solament fon purificat del pecat original lavors hoc encara de les sues coses e seqüeles que donen via a peccat axí com és ignorància, cobejança, fragilitat e omnipotència [sic] e de tota malícia ${ }^{43}$ (VCE $1,113,96 v, b)$.

\section{El CALVARIO de LA Redención en las fuentes Literarias}

El Credo de los Apóstoles une en un mismo artículo el descenso a los infiernos y la resurrección de Jesucristo porque realmente, la Pascua significa el dominio de Cristo sobre la muerte y el demonio y, por tanto, la liberación de las almas de los justos que estaban retenidos en el Sheol. Ahora bien, es necesario establecer una distinción entre el undécimo artículo del Credo apostólico y el tipo iconográfico del Calvario de la Redención que en este trabajo se relaciona exclusivamente con las vitae Christi que circularon coetáneamente por la ciudad de Valencia en el otoño de la Edad Media y principios de la Moderna y estas son la Vita Christi del cartujo Ludolfo de Sajonia, traducida por Roís de Corella, la Vida de Jesucrist de Francesc Eiximenis y la Vita Christi de Isabel de Villena.

Gregori $(2016,73)$ muestra una selección de obras que trataron el descendit ad inferos en la Valencia tardomedieval y establece tres fuentes para el tema iconográfico del calvario de la Redención: el sermón Surrexit. Non est hic

43 El séptimo privilegio es que Juan el Bautista fue purgado del pecado original en el seno materno, y esto porque fue santificado por la venida de Jesucristo a él, esto es, cuando la Gloriosa visitó a Isabel, según se ha dicho. Y dice aquí un doctor que no solamente fue purificado del pecado original sino también de sus secuelas que dan vía al pecado así como es ignorancia, codicia, fragilidad y omnipotencia y de toda malicia. predicado por san Vicente Ferrer con ocasión del domingo de Resurrección de 1413, la Vida de Jesucrist de Francesc Eiximenis y la Vita Christi de Isabel de Villena.

Ya se ha dicho, que el Calvario de la Redención expresa el tema de la contemplación de Jesús muerto en la cruz por parte de aquellos que estaban retenidos en el Sheol esperando el sacrificio de la Nueva Alianza. Se trata de un tipo iconográfico que se puede situar en la órbita de la contemplación de la humanidad de Jesucristo que toma la imaginación como su principal arma la cual no tiene más límites que la fe hi bones costumes (VCC I, 5b). La Redención, continuando con el pensamiento cristiano, es el punto culminante de la historia de la humanidad para lo cual, el Cartujano, al hablar del descenso de Cristo al Limbo, comienza con una secuencia que exhorta al lector a la alegría: "Acosta't tu, o ànima devota, si goses, o almenys de luny contempla, si pories sentir alguna centilla de aquella alegria, e humilment suplica que en algun temps sentir la pugues» ${ }^{44}$ (VCC, IV, 78v,a).

Al describir cuál hubo de ser el resultado de la liberación del pecado en los habitantes del Sheol que el demonio tenía atados, el Cartujano deja volar la imaginación y retrata a Satanás amarrado y muestra las puertas del infierno desquiciadas. Las almas siguen a Jesús hasta el Paraíso donde le esperarán hasta que acabe la cuarentena pascual y acuda allí:

Acostant-se l'alba del diumenge, les portes dels inferns levades e lo gran Sathanàs ligat en captiveri. La sua deífica ànima, primera, totes les altres lo seguien, hixqué de les infernals claustres, e portà al parahís terrenal aquella noble desferra de les remudes benaventurades ànimes $a b$ psalmòdies de veus angèliques, càntichs, himnes e jubilacions alegres. E·n aquest parahís volgué tinguessen la posada, fins al triumfo excel-lent de la sua ascensió gloriosa ${ }^{45}$ (VCC, IV, 78v,a).

El Cartujano continúa con una relación tipológica entre Jesucristo y algunos personajes veterotestamentarios y otros símbolos que lo prefiguraron:

Ara ha vençut, lo verdader Samsó, morint, los enemichs que.l escarnien; ara lo anyell sens màcula, en la sua sanch, la nit que morí, delliurà lo seu poble; ara fon la evangèlica paraula complida com lo fort armat, qui és lo diable, tenint en guarda lo seu palau, en lo qual los sants pares staven, vench lo més fort, Jesús, hi entrà en la sua casa e portà-se'n la sua desferra; ara.s mostra lo fort cavaller Banaýas que entrant al leó en la cisterna lo vencé e.l matà ab hun sol bastó que portava ${ }^{46}$ (VCC, IV, 78v,a).

44 Acércate, alma devota, si te atreves, o al menos, desde lejos, contempla si podrías sentir una chispa de aquella alegría y, humildemente, suplica si en algún momento la podrías sentir.

45 Acercándose el alba del domingo, las puertas del infierno apartadas y el gran Satanás atado en cautiverio; su deífica alma, en primer lugar, las otras lo seguían, salió de los claustros infernales y llevó al Paraíso terrenal aquellos nobles despojos de las bienaventuradas almas ya redimidas con salmodias de voces angélicas, cánticos, himnos y júbilos alegres. Y en este Paraíso quiso que tuviesen la posada hasta el triunfo excelente de su ascensión gloriosa.

46 Ahora ha vencido, el verdadero Sansón, muriendo, a los enemigos que lo escarnecían; ahora el cordero sin mancha, en su sangre, la noche que murió, libró a su pueblo; ahora fue la palabra angélica cumplida como el fuerte armado, que es el diablo, custodiando su palacio, en el cual los santos padres estaban, vino el más fuerte, Jesús, y entró en su casa y se llevó los despojos; ahora se muestra el fuerte 
En la narración del Cartujano, la alegría causada por la Salvación en los justos es inversamente proporcional a la tristeza producida en las almas del infierno:

Qui pot pensar aquella indicible amargor, inconsolable dolor, inestimable pena, que.Is miserables eternament dampnats sentiren quand les ànimes santes, ab lo seu redemptor Deu e senyor, dels inferns se partiren romanint ells en lo foch inestimable, en la immortal enveja, en lo verme de la conscicència, en les tenebres palpables e.n la mort que no passa perquè en aquest món no volgueren ni creure ni tembre? ${ }^{47}$ (VCC, IV, $78 v, a)$.

Según el Cartujano, Jesús, en su descenso al infierno, anuncia la obligación de regresar al sepulcro con la finalidad de que su alma pueda unirse al cuerpo para poder consumar la resurrección. Todos los justos le ruegan que regrese pronto al Paraíso porque quieren dar a su cuerpo glorioso la adoración que merece:

Stigué lo Senyor en lo Parahís poch spay ab la Santa Companyia e ab Enoch e Elies, los quals scriure no.s comporta quant de la sua vista se alegraren. Diu-los que ja és venguda la hora que lo seu sacratíssim cors del sepulcre cobre e que resuscitant lo glorifiquen que, axí obedient, li havia servit a la redempció humana e tots prostrats devotament lo preguen que prestament torne perquè molt desigen que ab lo seu cors gloriós lo adoren $^{48}$ (VCC, IV, 78v,a).

Evidentemente, la descripción de VCC no puede ser la fuente que inspiró a Macip porque el Cartujano, en su narración del descenso a los infiernos, sitúa los hechos en el domingo de Resurrección, menciona la separación del cuerpo y del alma y la unión que espera que se realice en breve; en cambio, el cuadro muestra a Jesús clavado en la cruz. ${ }^{49}$

caballero Benaía que entrando el león en la cisterna lo venció y lo mató con un solo bastón que llevaba.

47 ¿Quien puede pensar en aquella inefable amargura, inconsolable dolor, inestimable pena que los miserables eternamente condenados sintieron cuando las almas santas, con su redentor Dios y señor, se marcharon de los infiernos dejándolos a ellos en el fuego inestimable, en la envidia inmortal, con el gusano de la conciencia, con las tinieblas palpables y en la muerte que no pasa porque en este mundo no quisieron ni creer ni temer?

48 Estuvo el Señor en el Paraíso poco espacio con la Santa Compaña y con Henoc y Elías cuya alegría es imposible describir. Les dijo que ya había venido la hora en la que debía tomar, del sepulcro, su sacratísimo cuerpo y que resucitando lo glorifiquen que, así obediente, le había servido para la redención humana y todos postrados devotamente le ruegan que prestamente regrese porque desean intensamente adorarlo en su cuerpo glorioso.

49 Con el deseo de contemplar el cuerpo glorioso de Cristo, se interrumpe tanto la narración del Cartujano como la del sermón Surrexit. Non est hic de san Vicente Ferrer. Gregori (2016) establece entre las fuentes literarias del Calvario de la Redención el sermón que el santo valenciano predicó el domingo de Pascua de 1413. Aquí el dominico narra el deseo de los justos por ver la señal de las llagas de la pasión en el cuerpo glorioso de Cristo: Los sants pares, vehents que ere passat lo divendres, e la nit, e puys disapte, e puys la nit, ell desijaven tant que "vessen aquell gloriós cors ab aquelles naffres" que havia haguda la victoria (Ferrer 1927, 306). Del sermón de san Vicente se desprende que los justos no visitan el calvario y no contemplan el cuerpo Cristo colgando de la cruz, sino que ven el cuerpo glorioso saliendo del sepulcro: Jhesu Xrist entrá en lo moniment, e ysqué resuscitat gloriosament, [...] e "mostrá llavors lo seu preciós cors gloriós a aquells sants» (Ferrer 1927, 307). Por estas razones aducidas el sermón Surrexit. No est hic no puede contarse entre las fuentes literarias del Calvario de la
En dos ocasiones, -capítulos 117 y 123 - la Vida de Jesucrist de Francesc Eiximenis narra el descenso de Cristo al Sheol y, siguiendo a Teofilus, en el libro de Les revelacions dels Sants Pares de Egypte, cuenta como, al morir, Cristo fue recibido por tres jerarcas, cada uno en representación de las tres jerarquías angélicas.

Diu primerament que passat lo Salvador d'esta vida puntual tantost les tres Jerarchies de Paradís qui ja eren aquí esperants lo seu passament, lo adoraren ab la major reverència que pogueren, ço és, a la sua santa ànima unida ab la sua santa divinitat e cascun de ells, ço és, dels dits sants jerarches offerí-li special joyell de part del seu gloriós Pare per honor de la sua gran victòria e en guardó dels seus grans vituperis los quals tant virtuosament e ab tanta paciència havia soferits ${ }^{50}$ (VCE, 9, 117, 334a).

Cada uno de los tres jerarcas mencionados ofrece a Jesucristo un obsequio por medio del cual lo reconocen como rey del universo, señor de la historia y juez universal:

El primer jerarcha e cap de la primera jerarchia dels àngels celestial li posà lo primer joyell, dient-li que constituït era rey en lo cel e en la terra, e era fet rey de reys e senyor de senyors [...] E lo segon jerarcha li oferí nom e fama general per tot lo món [...] e qui.l hoirà nomenar en lo cel e en la terra o en lo abís infernal que de continent se ajenoll [...] Lo terç jerarcha li oferí de part del seu pare tenir lo juhí final sobre tota creatura ${ }^{51}$ (VCE, 9, 117, 334a).

Continúa Eiximenis contando cómo los representantes de les jerarquías angélicas, rogados por los santos padres - los justos del Antiguo Testamento- piden al Salvador ver el cuerpo que había sido el precio de la Redención.

Tots los dits tres jerarches demanaren al Salvador, a instància dels Sants Pares qui eren en lo Lim d'infern, que li plagués exohir lur gran desig que havien de veure lo seu preciós cors ans que fos sotsterrat, e açò perquè veesen com estava penjat en la creu, cor terribles coses los ne havien dites los àngels que lo.y havien vist pen$\operatorname{jar}^{52}$ (VCE, 9, 117, 334v,a).

Siguiendo la Vida de Jesucrist de Eiximenis, este deseo fue concedido y lo Santos Padres fueron liberados para acudir delante de la cruz:

\section{Redención.}

50 En el mismo instante del paso del Salvador de esta vida a la otra, las tres jerarquías del Paraíso, que ja esperaban su traspaso, lo adoraron con la mayor reverencia que pudieron, es decir, a su santa alma unida a su divinidad y cada uno de ellos le ofreció una joya especial de parte de su glorioso Padre por honor de su gran victoria y como premio a los vituperios que con tanta paciencia y tan virtuosamente había sufrido.

51 El primer jerarca y jefe de la primera jerarquía de los ángeles le puso la primera joya diciéndole que era constituido rey en el cielo y en la tierra, y rey de reyes y señor de señores. El segundo jerarca le ofreció nombre y fama por todo el mundo y de manera que quien oirá su nombre en el cielo y en la tierra o en el abismo infernal que inmediatamente se arrodille. El tercer jerarca le ofreció de parte de su Padre tener el juicio final sobre toda criatura.

52 Los tres jerarcas pidieron al Salvador, a instancia de los Santos Padres que estaban en el Limbo del infierno, que aceptase conceder el gran deseo que tenían de contemplar su precioso cuerpo antes de la sepultura para poder ver como estaba colgado en la cruz porque terribles cosas habían oído sobre esto a los ángeles lo habían visto crucificar. 
E diu que aprés que lo Salvador estech davallat en infern, e ach aquí preycat als Sants Pares, axí com diu sent Pere, lo Salvador pugà d'aquí, delliurant los Sants Pares e menà-los davant la creu ensenyant-los lo seu preciós cors qui encara estava penjat a mort en la $\mathrm{creu}^{53}$ (VCE, 9, 117, 334v,a).

Al llegar al Calvario y contemplar las heridas producidas por el cruel maltrato al Salvador, los santos Padres, haciendo memoria de la historia de la Salvación, pidieron venganza a Dios Padre.

O Senyor! Confon e gita de la terra aquesta malvada nació qui los sants prophetes ha morts e perseguits e déus estranys ha quaix totstemps adorats e elegits, e ara ha la sua mà posada en lo vostre Fill bena huyrat $\mathrm{e} \cdot \mathrm{I}$ ha axí aparellat perseguint e menyspreant e ala fi a tant lega mort l'à lliurat. O Senyor! E fets justícia al vostre fill d'aquesta maleyta generació per la vostra gran bonea ${ }^{54}$ (VCE, 9, 117, 334v,a).

Contrariamente, continúa fray Francesc, la Virgen pidió clemencia para el pueblo judío al cual pertenece ella y su hijo:

A la qual cosa atenent la gloriosa Mare de Déu, que levada en sperit tot acò veya, suplicà a aquella sancta ànima del seu fill que ell no destrouís axí aquell poble del qual ell era exit mas que, per sa reverència e honor dels grans patriarches d'on era davallat, e per amor de ella, e per tal com n'i havia molts qui havien peccat contra ell per ignorància, que.Is esperàs en lur conversió e.Is trametés informadós qui-Is reduhissen a la veritat ${ }^{55}$ (VCE, 9, 117, 334v,b).

Eiximenis indica que la Mare de Déu, que levada en sperit tot acò veya. Es decir, la Virgen, por especial concesión, contempla, en un arrobo místico, los santos del paraíso situados alrededor de la cruz de su hijo.

Como ha quedado dicho, sor Isabel de Villena también narra el descenso de Cristo al Sheol. Ella, que nunca pierde de vista su protocolario pasado cortesano, describe la llegada de Jesús al Limbo como una entrada real en la que san Miguel es el encargado de preparar un trono adecuado para tan singular ocasión:

E lo Senyor mana a sanct Miquel que trametes misatgeria al pare Adam e a tots los altres denunciant la sua venguda. E lo dit sanct Miquel crida dos Princeps, ab molts altres angels quils acompanyaven, e dixlos: "Cuytau als Lims, e digau als senyors qui aquí son que salegren es meten a punct, que la Magestat

53 Y dice que después que el Salvador bajó al Infierno y hubo predicado a los Santos Padres, así como dice san Pedro, el Salvador subió de allí, librando a los Santos Padres y los mandó delante de la cruz enseñándoles su precioso cuerpo que, muerto, aún pendía de la cruz.

54 ¡Oh Señor! Confunde y expulsa de la tierra esta malvada nación que ha perseguido y matado a los profetas y ha elegido y adorado a dioses extraños y ahora ha puesto su mano sobre tu bienaventurado Hijo y lo ha entregado a la muerte. iOh Señor! Por tu gran bondad, haz justicia sobre esta maldita generación a tu Hijo.

55 Atenta a esto la gloriosa Madre de Dios, que elevada en su espíritu todo esto veía, suplicó a aquella santa alma de su hijo que no destruyese el pueblo del que había salido sino que, por reverencia y honor de los grandes patriarcas de donde descendía, por amor de ella y porque muchos de los judíos habían pecado contra él por ignorancia que esperase a su conversión y les mandase adoctrinadores que los condujesen a la verdad. del Senyor sera molt prest ab ells. E vosaltres feu aparellar lo strado e la cadira real dins los Lims, car aquí vol reposar sa senyoria estos tres dies». E, los missatgers partits, tota laltra multitud que restava, metent se en proceso començaren a cantar Te Deum laudamus. $\mathrm{E}$ sanct Miquel, portant la bandera levada anava davant lo Senyor. E axi començaren son camís6 $(\mathrm{VCV}, 3,6)$.

En VCV, el alma de Jesús estuvo tres días en el Limbo esperando unirse al cuerpo. La abadesa de la Trinidad, que escribe para un público femenino, siempre tiene presente la captatio benevolentiae y atribuye a las mujeres el deseo piadoso de contemplar el cuerpo de Jesús muerto en la cruz.

E les dones, qui per natura son pus amables que los homens, e nenguna cosa que de recordar sia per satisfer a la obligacio de la amor divina a elles no era en oblit, digueren, entre si mateixes: «O si podiem veure lo cors del Senyor nostre qui encara penja en la creu! ${ }^{57}$ (VCV, 3, 49).

En la dramatización escrita por la abadesa de la Trinidad, Dios Padre ordena a san Miguel que envíe un mensaje a Adán y a todos los habitantes del Limbo para que se alegren y preparen la llegada de Jesús allí. Sor Isabel, educada en la corte de la reina María de Castilla y buena conocedora de los protocolos áulicos no olvida situar a Jesús en el trono real colocado sobre un estrado. En VCV, las mujeres hablan con Eva, y esta con Adán el cual se postra delante del trono de Dios:

E totes, desijoses de obtener aquesta gracia, acostaren se a la mare gloriosa Eva, [...] E la gloriosa Eva [...], acostas a Adam [...] E Adam, levant se molt prest de la cadira, pres Eva per la ma per anar a fer la dita supllicacio; e, venint davant lo Senyor, [...] E lo Senyor, ab cara molt alegra respos dient: «Adam, so molt content de satisfer a la demanda vostra ${ }^{58}$ (VCV, 3, 49).

En la obra de la de Villena, los justos contemplan el Calvario por medio de una visión, sens exir de aquell loch:

E tantost fon fet un cami de aquí hon ells staven fins a Monticalvari, e sens exir de aquell loch los paregue esser tots entorn de la creu e veure lo cors del Senyor molt clarament e adorant aquell ab profunda humilitat, car la divinitat sua nunqua desempara aquell sagrat cors, ans fon tostemps ab la anima e ab lo cors, ab tot

$56 \quad$ Y el Señor ordenó a san Miguel que enviase un mensaje al padre Adán y a todos los otros. Y el dicho san Miguel llamó a dos príncipes, con muchos otros ángeles que les acompañaban y les dijo: «Acercaos al Limbo y decid a los señores que allí están que se alegren y se preparen, porque la majestad del Señor legará pronto. Y vosotros preparad un estrado con el trono real en el Limbo porque allí quiere reposar su señoría estos tres días». Y marchándose los mensajeros, el resto de la multitud que quedaba comenzaron a cantar Te Deum laudamus. Y san Miguel, llevando la bandera en alto, marchaba delante del Señor. Y así empezaron su camino.

$57 \quad Y$ las mujeres, que por naturaleza son más amables que los hombres y nunca dejan en el olvido ninguna obligación del amor divino, dijeron dentro de sí: «¡Oh, si pudiésemos ver el cuerpo de nuestro Señor que aún pende de la cruz!».

$58 \quad Y$ todas, deseando obtener la gracia, se acercaron a la gloriosa Eva y la gloriosa Eva se acercó a Adán y Adán, levantándose muy rápidamente de la silla, tomó a Eva por la mano para ir a hacer la súplica y viniendo delante del Señor. Y el Señor, con cara muy alegre respondió diciendo: «Adán, estoy muy contento de poder satisfacer vuestra petición». 
fossen separats per mort; e per ço aquell excellent cors devia esser adorat de adoració latria e axí fon fet per tots aquells gloriosos sancts ${ }^{59}$ (VCV, 3, 49).

\section{CONCLUSIONES}

Se han podido mostrar a lo largo del presente trabajo unas premisas teológicas que sitúan el Calvario de la Redención de Vicent Macip dentro de las piezas destinadas tanto a la instrucción de los fieles como a la piedad personal de estos. Así, este cuadro explica por vía visual la muerte redentora de Cristo, el valor universal de la Redención y la superioridad del sacrificio de Cristo respecto del culto levítico y, al mismo tiempo, materializa los elementos necesarios para la contemplación de uno de los artículos del Credo: descendit ad inferos.

Esta pieza, evidencia clara del movimiento piadoso y estético de contemplar la humanidad de Cristo, muestra la genealogía humana de Jesús de Nazaret insertándolo entre los descendientes de Adán y Eva y, para mayor evidencia, de sus abuelos Joaquín y Ana. En esta misma línea, se pone de relieve la presencia de Abraham y David, los dos hitos más importantes para establecer tres grupos de catorce generaciones que van de la antigua a la nueva alianza, es decir, la línea que va de Adán a Cristo y que justifica que Jesús es el mesías hijo de Abraham y del linaje real de David.

No se pueden asegurar con firmeza las fuentes literarias en las que Macip se pudo inspirar, ahora bien, ningún elemento del cuadro parece pintado al azar, bien al contrario, todos presentan una buena fundamentación teórica que va más allá de la pura disposición estética y que hacen suponer una documentación bien precisa. Para poder aproximar una interpretación del discurso visual, nos hemos tenido que basar, por tanto, en aquello que en la historia del arte se entiende como fuentes indirectas.

El tema pintado por Macip aparece tanto en la Vida de Jesucrist de Francesc Eiximenis como en la Vita Christi de Isabel de Villena. Al explicar el descenso a los infiernos, ambas obras hacen que los justos contemplen a Jesús muerto y clavado en la cruz pero las narraciones no son del todo coincidentes. Eiximenis sitúa a los justos en el Calvario mientras que la Virgen contempla la visita en un arrobo; en cambio, en la Vita Christi de Isabel de Villena, los justos contemplan el Calvario en una visión.

Se ha observado el paralelismo existente entre la narración escrita por Francesc Eiximenis en la Vida de Jesucrist y la representación pintada por Macip en el Calvario de la Redención. El primero habla de una visión, de un arrobo de la Virgen en el que le es concedido contemplar, alrededor de la cruz de Jesús, a todos los santos rescatados del Sheol; Macip pinta una Virgen de espaldas a la cruz, con los ojos cerrados y las manos entrelazadas formando un círculo con los brazos, todo indicios de una actitud contemplativa. Tal

59 E inmediatamente se abrió un camino desde donde estaban hasta el monte Calvario, y sin salir de aquel lugar les pareció estar todos entorno de la cruz y ver el cuerpo del Señor muy claramente. Y adorándolo con profunda humildad, pues su divinidad nunca abandonó aquel sagrado cuerpo, antes bien estuvo siempre unida al alma y al cuerpo, aunque estos estuviesen separados por la muerte; y por esto aquel cuerpo excelente debía ser adorado con adoración de latría. Y así se hizo por parte de aquellos gloriosos santos. vez la intención del artista fue mostrar el arrobo de la Virgen contado por el franciscano en su Vida de Jesucrist.

Para avanzar en la confirmación de esta hipótesis sería necesario adentrarnos en la recepción de la obra de Eiximenis y en la catalogación de las obras literarias de las que dispuso Macip para diseñar los programas iconográficos de las piezas que pintaron tanto él mismo como los miembros de su taller. Pero todo esto sería materia de otro trabajo.

\section{FUENTES}

Bonaventura, Pseudo. 1868. Meditationes Vitae Christi en Sancti Bonaventurae. Opera Omnia. 15 vols, Ed A.C. Peltier, vol XII, 509-630. Paris: Bibliopola.

Breydenbach, Bernhard von. 1498. Viaje de la Tierra Santa. Trad. Martín Martínez de Ampies. Zaragoza: Pablo Hurus.

Casale, Ubertinus de. 1485. Arbor vitae crucifixae Jesu Christi. Venecia: Andreas de Bonetis.

Eiximenis, Francesc. Primer llibre del Crestià. ms 40, Arxiu de la Catedral de València.

Eiximenis, Francesc. Vita Christi. ms 209. Biblioteca Universitària de Valencia.

Guigues, le Chartreux. 1970. Lettre sur la vie contemplarive (l'échelle des moines) Douze méditations. Edición Edmund Colledge y James Walsh. París: Éditions du Cerf.

Malla, Felip de. 1980. Memorial del pecador remut. Edición de Manuel Balasch. 3 vols. Barcelona: Barcino.

Sajonia, Ludolfo de. 1495. Meditationes vitae Christi, Lo quart del Cartoxà o Vida de Jesús / arromançat per Johan Roiç de Corella. València: Lope de la Roca.

Villena, Isabel de. 1916. Llibre anomenat Vita Christi. Edición de Ramon Miquel i Planas. 3 vols. Barcelona: Biblioteca Catalana.

\section{BIBLIOGRAFÍA}

Albi, José. 1979. Joan de Joanes y su círculo artístico. 3 vols. Valencia: Institución Alfonso el Magnánimo.

Baier, Karl. 2009. «Meditation and Contemplation in High to Late Medieval Europe». En Yogic Perception, Meditation and Altered States of Consciousness, ed. Eli Franco, 325-349. Wien: Österichische Akademie der Wissenchaftern.

Benito, Fernando. 1981. «Vicente Macip y Joan de Joanes. Semejanzas y diferencias de un estilo pictórico similar». Debats 1: 40-43.

Benito, Fernando. 1988. «Sobre la influencia de Sebastiano del Piombo en España: a propósito de dos cuadros suyos en el Museo del Prado». Boletín del Museo del Prado 9: 5-28.

Benito, Fernando. 1993. «El maestro de Cabanyes y Vicente Macip. Un solo artista en etapas distintas de su carrera». Archivo Español de Arte LXVI, 263: 223-244.

Benito, Fernando y José Luis Galdón, coord. 1997a. Vicent Macip (c. 1475-1550): Museu de Belles Arts de València, del 4 febrer-20 abril 1997. València: Consorci de Museus de la Comunitat Valenciana.

Benito, Fernando y José Luis Galdón. 1997b. «Retablo de San Dionisio y Santa Margarita». En Catálogo de la exposición Vicente Macip (h. 1475-1550). Valencia: Museo de Bellas Artes de Valencia - Generalitat Valenciana.

Benito, Fernando y José Gómez Frechina, coord. 2001. La clave flamenca en los primitivos valencianos: [exposición] Museo de Bellas Artes de València, del 30 de mayo al 2 de septiembre de 2001. València: Consorci de Museus de la Comunitat Valenciana.

Benito, Fernando y José Gómez Frechina, coord. 2006. La col/lecció Orts-Bosch al Museu de Belles Arts de València. València: Generalitat Valenciana.

Brines, Lluís. 2004. La filosofía social y política de Francesc Eiximenis. Sevilla: Grupo Nacional de Editores.

Cerveró, Luis. 1966. «Pintores valentinos. Su cronología y documentación». Archivo de Arte Valenciano XXVII: 19-30.

Company, Ximo y Lluïsa Tolosa. 1997. «Petjades joanesques a la Safor. Reflexions sobre el codi lingüístic més important de la pintura va- 
lenciana del segle XVI». En Miscel/lània Josep Camarena, 101-127. Gandia: CEIC Alfons el Vell.

Company, Ximo y Lluïsa Tolosa. 1999a. "De pintura valenciana: Bartolomé Bermejo, Rodrigo de Osona, el Maestro de Artés, Vicente Macip y Joan de Joanes». Archivo Español de Arte 287: 268-278. https://doi.org/10.3989/aearte.1999.v72.i287.764

Company, Ximo y Lluïsa Tolosa. 1999b. «La obra de Vicente Macip que debe restituirse a Joan de Joanes». Archivo de Arte Valenciano LXXX: 50-61.

Denzinger, Heinrich. 1951. Enchiridion Symbolorum: definitionum et declarationum de rebus fidei et morum. Barcelona: Herder.

Ferrer, Albert y Estefanía Ferrer. 2015. «El genio creativo de Joan de Joanes a través de algunas de sus obras maestras». Cuadernos de Arte de la Universidad de Granada 46: 3-14. https://revistaseug. ugr.es/index.php/caug/article/view/5126

Ferrer, Albert y Estefanía Ferrer. 2016. "Influencias flamencas en la obra de Joan de Joanes a través de las colecciones de Mencía de Mendoza». De Arte: Revista de Historia del Arte 15: 78-95. http:// doi.org/10.18002/da.v0i15.3683

Ferrer, Sant Vicent. 1927. Quaresma de Sant Vicent Ferrer: predicada a València I'any 1413. Ed. Josep Sanchis Sivera. Barcelona: Institució Patxot.

Feuillet André. 1985. «L'Eucharistie, le Sacrifice du Calvaire, et le Sacerdoce du Christ, d'après quelques données du Quatrième Évangile, comparaison avec les Synoptiques et l'Épitre aux Hébreux». Divinitas 29: 103-149.

Garín y Ortiz de Taranco, Felipe María. 1955. Catálogo-Guía del Museo Provincial de Bellas Artes de San Carlos. Valencia: Institución Alfonso el Magnánimo.

Gregori, Rubén. 2016. «Origen y fuentes textuales del Calvario de la Redención. Aproximación a la representación de los patriarcas venerando la imagen de Cristo en la cruz». Revista Digital de Iconografía Medieval VIII, 15: 67-87. https://www.ucm.es/data/cont/ docs/621-2016-06-30-Gregori_Calvario.pdf

Hauf, Albert. 1990. D'Eiximenis a sor Isabel de Villena: aportació a l'estudi de la nostra cultura medieval. València: IVF-PAM.

Hauf, Albert. 1998. "Text, pintura i meditació: El Speculum Animae atribuït a Sor Isabel de Villena, i la funció empàtica de l'art religiós». En Actes del VII Congrés de l'Associació Hispànica de Literatura Medieval, ed. Santiago Fortuño Llorens y Tomàs Martínez Romero, I, 3-57. Castelló de la Plana: Servei de Publicacions Universitat Jaume I.

Hauf, Albert. 2000. "Corrientes teológicas valencianas, s. XIV—XV: Arnau de Vilanova, Ramón Llull y Francesc Eiximenis». En Actas del
X Simposio de Teología Histórica. Teología en Valencia: Raíces y retos, buscando nuestros orígenes de cara al futuro, 729-745. Valencia: Publicaciones de Facultad de Teología San Vicente Ferrer.

Heil, John Paul. 1995. «Jesus as the Unique High Priest in the Gospel of John». Catholic Biblical Quartely 57: 729-745.

Lerner, Robert. 2006. «Eiximenis i la tradició profètica». Llengua \& Literatura 17: 7-28. http://revistes.iec.cat/index.php/LLiL/article/ view/1179/44654

Martínez Aloy, José. 1909-1910. La Casa de la Diputación. Valencia: Tipografía Doménech.

Ocáriz, Fernando. 1982. "La resurrección de Jesucristo». En Memorias del III Simposio Internacional de Teología de la Universidad de Navarra, ed. Lucas Mateo Seco, 749-773. Pamplona: Servicio de Publicaciones de la Universidad de Navarra.

Panofsky, Erwin. 1953. Early Netherlandish Paintings. Its Origins and Character. Cambridge: Harvard University Press.

Samper, Vicente. 1994. «Una tabla de Santa Ana, la Virgen y el Niño junto a María Magdalena, identificable con la central del retablo de los Joan (1507) de Vicente Macip». Archivo de Arte Valenciano 85: 35-38.

Samper, Vicente. 2001. "Documentos inéditos para la biografía de los Macip». Archivo Español de Arte LXXIV 294: 163-171. https://doi. org/10.3989/aearte.2001.v74.i294.392

Sanchis Sivera, José. 1909. La catedral de Valencia. Guía histórica y artística. Valencia: F. Vives Mora.

Tena, Pedro. 1998. «Reivindicación de Bernardo de Breidenbach huella de la literatura medieval alemana en España». En Actas del IV Congreso Internacional de la Asociación Internacional Siglo de Oro, edición de María Cruz García de Enterría y Alicia Cordón. Alcalá de Henares: Universidad de Alcalá.

Tolosa, Lluïsa, Ximo Company y Lorenzo Hernández. 2006. «De nuevo sobre Joan Macip, alias Joan de Joanes (c. 1505-1510-1579)». En De pintura valenciana (1400-1600). Estudios y documentación. Coordinado por Lorenzo Hernández Guardiola. Alicante: Instituto Alicantino de Cultura Juan Gil Albert.

Tormo, Elías. 1932. Valencia: Los Museos. Madrid: Centro de Estudios Históricos.

Vallés, Vicent y Fernando Benito. 1991. "Nuevas noticias de Vicente Macip y Joan de Joanes». Archivo Español de Arte LXIV, 255: 353360.

Vanhoye, Albert. 1980. Prêtres anciens, prêtre nouveau selon le Nouveau Testament. Paris: Seuil. 